\title{
How Important Is Precommitment for Monetary Policy?
}

\author{
Richard Dennis ～Ulf Söderström*
}

September 2002

\begin{abstract}
Economic outcomes in dynamic economies with forward-looking agents depend crucially on whether or not the central bank can precommit, even in the absence of the traditional "inflation bias." This paper quantifies the welfare differential between precommitment and discretionary policy in both a stylized theoretical framework and in estimated data-consistent models. From the precommitment and discretionary solutions we calculate the permanent deviation of inflation from target that in welfare terms is equivalent to moving from discretion to precommitment, the "inflation equivalent." In the estimated models, using a range of reasonable central bank preference parameters, the "inflation equivalent" ranges from 0.05 to 3.6 percentage points, with a mid-point of either 0.15 or $1-1.5$ percentage points, depending on the model. In addition to the degree of forward-looking behavior, we show that the existence of transmission lags and/or information lags is crucial for determining the welfare gain from precommitment.
\end{abstract}

Keywords: Optimal monetary policy; stabilization bias; precommitment; discretion.

JEL Classification: E52; E58.

${ }^{*}$ Dennis: $\quad$ Economic Research Department, Mail Stop 1130, Federal Reserve Bank of San Francisco, 101 Market Street, San Francisco, CA 94105, USA, richard.dennis@sf.frb.org; Söderström: Research Department, Sveriges Riksbank, SE-103 37 Stockholm, Sweden, ulf.soderstrom@riksbank.se. We are grateful to Henrik Jensen, Marianne Nessén, Athanasios Orphanides, Øystein Røisland, Glenn Rudebusch, Pierre Siklos, Frank Smets, Paul Söderlind, Anders Vredin, Carl Walsh, and seminar participants at Sveriges Riksbank, Norges Bank, and UC Davis for comments. We also thank John Williams for providing the variance-covariance matrix for the Fuhrer-Moore model. The views expressed in this paper are solely the responsibility of the authors and should not be interpreted as reflecting the views of the Federal Reserve Bank of San Francisco, the Federal Reserve System, or the Executive Board of Sveriges Riksbank. 


\section{Introduction}

Institutions and policy regimes can have widespread and important implications for social welfare. This is as true for monetary policy as it is for other policymaking contexts. Within the monetary policy literature the assumption of rational expectations is widespread. However, rational expectations complicate the policymaking process because the method by which policy is expected to be set in the future affects the choices that forward-looking firms and households make today. The importance of rational expectations for policymaking was forcefully brought home by Kydland and Prescott (1977). They showed that optimal policies require that the policymaker be able to precommit to a policy rule, but that such a rule is not time-consistent. At the same time, time-consistent policies are suboptimal, leading to lower welfare. In the context of monetary policy, Kydland and Prescott and subsequently Barro and Gordon (1983) demonstrated that pursuing time-consistent policies could produce inefficiently high inflation. Indeed, an "inflation bias" is one explanation for the high inflation experienced in the United States during the 1970s and early 1980s. ${ }^{1}$

The inflation bias result is well known and has been thoroughly analyzed in the literature. This paper deals with another, less well-known, consequence of the time consistency problem, often called "stabilization bias." While the inflation bias is associated with the average inflation rate that prevails in steady state and is usually analyzed in "static" models, stabilization bias is strictly a dynamic phenomenon that describes the fact that the transition path the economy takes from its initial state toward its asymptotic equilibrium depends on whether the monetary authority can precommit to a policy rule. Thus, stabilization bias affects the volatility of the economy out of steady state rather than the steady state itself. ${ }^{2}$ It is the effect that stabilization bias has on welfare that is the focus of this paper.

Although the mechanisms underlying the stabilization bias are implicit in the earlier literature on optimal control (see, e.g., Kydland and Prescott, 1980), it was brought to popular attention by Svensson (1997b), Clarida et al. (1999), and Wood-

\footnotetext{
${ }^{1}$ See Sargent (1999). Ireland (1999) tests this hypothesis with mixed results; support for the inflation bias hypothesis can be found in trend relationships between series (inflation and unemployment in Ireland's framework), but shorter-run fluctuations contradict the hypothesis.

${ }^{2}$ While the inflation bias rests on the assumption that the monetary authorities aim for a rate of unemployment below the natural rate (or, equivalently, a level of output above the potential level), the stabilization bias is also present when the unemployment target is equal to the natural rate. Thus, McCallum's (1997) and Blinder's (1998) criticisms of the assumptions underlying the inflation bias do not apply to the stabilization bias result.
} 
ford (1999b). ${ }^{3}$ Woodford, in particular, shows that, for a widely employed measure of social welfare, the stabilization bias manifests itself in the form of insufficient monetary policy inertia. In an economy with forward-looking agents, a more gradual policy response to shocks helps stabilize expectations, which in turn promotes economic stability. But such a policy response demands that the central bank live up to its past promises and continue with its response even after the shock itself has passed. A central bank that reoptimizes each period would choose not to continue with the gradual response, making the optimal policy time-inconsistent.

In the time-consistent (discretionary) equilibrium, output is over-stabilized while inflation is too volatile, leading to lower welfare than under precommitment. We attempt to quantify the welfare gain from precommitment, i.e., the magnitude of the welfare differential caused by the stabilization bias. Of course this magnitude is model specific. Consequently, the impact any stabilization bias has on welfare is ultimately an empirical question to be examined using estimated models.

Numerous studies have examined the performance of simple rules while assuming precommitment. At the same time, very few studies have considered how a policymaker's inability to precommit affects welfare in dynamic models. Clarida et al. (1999) (CGG) develop a simple New-Keynesian model and use it to derive optimal precommitment rules and optimal discretionary rules. A major attraction of their model is its analytic tractability. It is primarily its tractability that has made it a popular framework for analysis rather than its empirical support (Estrella and Fuhrer, 1998). Dennis (2000) considers the CGG model and the forward-looking model estimated by Rudebusch (2002). In the CGG model the welfare gain from precommitment (the reduction in social loss associated with moving from discretion to precommitment) ranges from $0 \%$ to $11 \%$, depending on policy objectives, while in the Rudebusch model precommitment generates only small improvements in welfare $(0.12-0.26 \%)$ for optimized Taylor-type rules and nominal income growth rules.

McCallum and Nelson (2000) employ the CGG model to examine welfare under optimal discretionary rules and timelessly optimal rules ${ }^{4}$ and find that timelessly

\footnotetext{
${ }^{3}$ See also Woodford (1999a) for a non-technical discussion.

${ }^{4}$ Timelessly optimal rules were first developed by Woodford (1999a) and are developed further by Svensson and Woodford (1999) and analyzed by Dennis (2001c), and differ from precommitment rules (Currie and Levine, 1993) in that private agents' expectations are not exploited in the initial period. Such rules are not optimal from the perspective of any given point in time and need not generate outcomes that are superior to discretion (McCallum and Nelson, 2000; Dennis, 2001c; Blake, 2001). Unfortunately, timelessly optimal rules are not unique (Svensson and Woodford, 1999; Dennis, 2001c; Giannoni and Woodford, 2001) and this hinders their application to welfare analysis.
} 
optimal rules produce a welfare gain ranging from $0 \%$ to $64 \%$ (see their Tables 1 and 2). Dennis (2001a) considers welfare under precommitment and discretion using both a version of the Fuhrer and Moore (1995b) model estimated by Huh and Lansing (2000) and a slightly modified version of the CGG model. In the Huh-Lansing model precommitment leads to a $6 \%$ improvement in welfare whereas in the modified CGG model welfare improves by $9 \%$. Vestin (2001) also modifies the CGG model and analyzes the improvement in welfare obtained through precommitment. Unlike the studies above, Vestin considers a wide range of parameter values and finds welfare improvements anywhere between $0 \%$ and $57 \%$ (see his Figure 3). Ehrmann and Smets (2001) analyze a "hybrid" New-Keynesian model (with both forwardand backward-looking elements) estimated by Smets (2000) on euro area data and find that precommitment leads to welfare gains between $17 \%$ and $31 \%$. It is thus clear that in the CGG model and other New-Keynesian specifications, the model's parameterization can have dramatic effects on the welfare differential obtained.

In this paper we investigate the degree to which precommitment can improve welfare. We employ a range of models for this task. We begin by analyzing a stylized model (similar to that estimated by Smets, 2000) that encompasses the frameworks considered by Clarida et al. (1999), McCallum and Nelson (2000), and Vestin (2001), and we use this model to solve for both precommitment and discretionary equilibria. An important feature of this stylized model is that it encompasses both "sticky price" and "sticky inflation" specifications. ${ }^{5}$ Thus we can use the stylized model to show how the importance of precommitment is affected by parameter variations that bridge the gap between these two classes of New-Keynesian models. Moreover, the model allows us to identify features that lead to greater welfare differentials (such as the effect of habit formation and the nature of wage contracts). We also consider how explicit lags in the transmission mechanism and the information set agents use to form expectations affect the stabilization bias.

As emphasized above, the importance of the time-consistency problem is ultimately an empirical issue. Therefore, with the stylized model as a guide, we also examine three estimated models of varying levels of complexity: models fitted to quarterly U.S. data by Rudebusch (2002), Fuhrer and Moore (1995b), and Orphanides and Wieland (1998). These estimated models are similar in vein to the

\footnotetext{
${ }^{5}$ Sticky price models are often derived from Calvo (1983) style price contracts, Taylor (1980a,b) style wage contracts, or costly price adjustment models (Rotemberg, 1982). Sticky inflation models are more usually based on both wage and price rigidities, such as relative real wage contracts (Buiter and Jewitt, 1981; Fuhrer and Moore, 1995b), or derived from sticky price models assuming some backward-looking elements in agents' expectations formation.
} 
stylized model, in that they are forward-looking and contain some nominal rigidity that gives monetary policy influence over aggregate demand and inflation, but they differ in terms of model specification and parameter values. We solve for optimal discretionary rules and optimal precommitment rules in each of these three models and calculate the welfare gain from precommitment. ${ }^{6}$ Our focus on estimated models allows us to say something about the welfare gain that might reasonably be achieved in actual economies, which gives our results more relevance than those from stylized constructs.

The structure of the paper is as follows. In Section 2 we describe and motivate the objective function used for welfare comparisons. Section 3 introduces and analyzes the stylized model. In Section 4 we first provide an overview of the estimated models; then we solve for optimal precommitment rules and optimal discretionary rules for a wide range of objective function specifications, calculate the welfare differential, and discuss the results. Section 5 concludes.

\section{Welfare}

Our analysis requires a measure of social welfare. For some models the representative agent's discounted life-time utility provides an obvious and natural measure of social welfare. However, in the monetary policy literature it is widely accepted that central banks should be concerned with inflation and some measure of real activity (see, e.g., Svensson, 1999). Thus, it is common practice to summarize social welfare through an objective function that penalizes squared deviations in inflation from target and squared deviations in output from potential $;^{7}$ many studies also build interest rate smoothing into the objective function (e.g., Rudebusch and Svensson, 1999). Woodford (2001) derives the conditions under which the standard objective function correctly represents a quadratic approximation to the representative agent's utility function. ${ }^{8}$ Aside from the stylized model, the models examined in this paper

\footnotetext{
${ }^{6}$ This paper is the first to calculate fully optimal rules under discretion and precommitment for the Fuhrer and Moore (1995b) and Orphanides and Wieland (1998) models. Each of these models has previously been solved in terms of optimal simple rules (see Fuhrer, 1997a; Orphanides and Wieland, 1998; and Levin et al., 1999), but fully optimal rules have not (to our knowledge) previously been examined in these models.

${ }^{7}$ Important references here include Taylor (1979) who uses the standard objective function in an early application of optimal monetary policy; Svensson (1997a) who shows the relationship between the standard quadratic objective function and the widespread practice of inflation forecast targeting; and the conference volumes edited by Bryant et al. (1993) and Taylor (1999).

${ }^{8}$ Woodford's result allows standard linear-quadratic methods to be applied to representative agent models. Applications include Erceg et al. (2000), Fuhrer (2000), Batini et al. (2001), and
} 
do not have explicit micro-foundations. ${ }^{9}$ Therefore, we take the standard "primal" approach and represent social welfare through the loss function

$$
L_{t}=(1-\delta) \mathrm{E}_{t} \sum_{j=0}^{\infty} \delta^{j}\left[\pi_{t+j}^{2}+\lambda y_{t+j}^{2}+\nu\left(i_{t+j}-i_{t+j-1}\right)^{2}\right],
$$

where $\pi_{t}, y_{t}$, and $i_{t}$ are the rate of inflation, the output gap (the percentage deviation of output from its "natural" level), and the nominal one-period interest rate, respectively; $0<\delta<1$ is a discount factor; and $\lambda, \nu \geq 0$ are the relative weights on output stabilization and interest rate smoothing. Without loss of generality, the target for inflation is normalized to zero.

In the general formulation of the objective function we include a nominal interest rate smoothing term, $\nu\left(i_{t+j}-i_{t+j-1}\right)^{2}$, as it is widely believed that central banks smooth interest rates, responding to shocks in sequences of small serially correlated interventions (Lowe and Ellis, 1997). More generally, an interest rate smoothing term helps optimal rules replicate the time-series characteristics of short-term interest rates (see, e.g., Söderström et al., 2002). On theoretical grounds, such a term has been motivated by central bank concerns about financial market stability (Cukierman, 1991; Goodfriend, 1991). Because many papers include interest rate smoothing, it is relevant to see how its presence affects the results. Of course, the situation without smoothing $(\nu=0)$ is also of interest, and we discuss that environment as well.

To evaluate the welfare differential between discretionary policy and precommitment we use two alternative measures. The first measure is the "percentage gain in welfare" associated with moving from the discretionary policy to precommitment;

$$
\Omega=100\left[1-\frac{L_{c}}{L_{d}}\right],
$$

where $L_{c}$ and $L_{d}$ are the values of the social loss function under precommitment and discretion. While this percentage gain from precommitment a priori may seem a natural measure of the welfare differential, it has no simple economic interpretation. As an alternative measure, we therefore follow Jensen (2001) and calculate the permanent deviation of inflation from target that in welfare terms is equivalent

Smets and Wouters (2002). Steinsson (2000) derives a similar welfare function in a model with endogenous persistence in inflation due to rule-of-thumb price setting. His approximation is slightly different, however, in that it also includes the variance of changes in inflation.

${ }^{9}$ Some micro-foundations for the stylized model can be found in Walsh (1998), Steinsson (2000), and McCallum and Nelson (1999). 
to moving from discretion to precommitment. This "inflation equivalent" is given by $^{10}$

$$
\hat{\pi}=\sqrt{L_{d}-L_{c}}
$$

The two welfare measures, (2) and (3), are not monotonically related; a given difference in loss can translate into very different ratios, depending on the initial level of loss. In particular, when the losses under precommitment and discretion both approach zero, but the loss under discretion approaches zero at a faster rate, the ratio in (2) can grow very large while the difference in (3) falls. Because it is more readily interpretable, and because it does not require division involving (potentially) small numbers, in the analysis that follows we largely focus our discussion on the inflation equivalent measure of the welfare gain. However, we report both the inflation equivalent and the percentage gain in welfare where possible so that our results can be more easily compared to those in other studies.

Finally, note that with the objective function (1) we have effectively eliminated any incentive for the policymaker to try to permanently generate positive output gaps, because the target for the output gap is zero. Removing this incentive eliminates any inflation bias and allows us to focus on the welfare implications of the stabilization bias. ${ }^{11}$

\section{A Stylized Macro-Model}

This Section analyzes a streamlined version of the dynamic models commonly used in the monetary policy literature. The model's simple structure allows us to identify those mechanisms that are most important in determining the gain from precommitment. At the same time, the model allows for different degrees of forwardlooking behavior in both inflation and output. Thus, it encompasses both the purely forward-looking models of Rotemberg and Woodford (1997), McCallum and Nelson (1999), and Clarida et al. (1999) and more backward-looking specifications, such as

\footnotetext{
${ }^{10}$ To calculate the inflation equivalent, note that a permanent deviation of inflation from target of $\hat{\pi}$ percent results in an increase in the objective function (1) of $(1-\delta) \sum_{j=0}^{\infty} \delta^{j} \hat{\pi}^{2}=\hat{\pi}^{2}$ (measuring inflation in percentage terms, so $\left.\pi_{t}=100 \Delta \log p_{t}\right)$. Thus the inflation equivalent satisfies $L_{c}+\hat{\pi}^{2}=$ $L_{d}$. Likewise, an "output gap equivalent" can be calculated as $\hat{y}=\sqrt{\left(L_{d}-L_{c}\right) / \lambda}=\hat{\pi} / \sqrt{\lambda}$.

${ }^{11}$ King and Wolman (1999) examine a model in which an inflation bias and a stabilization bias both occur. In their model the inflation bias affects welfare because with staggered prices inflation induces relative price distortions. If staggered prices were the only rigidity the optimal rate of inflation would be zero. But in their model an inflation bias occurs because the monetary authority attempts to use monetary policy to mitigate resources lost through a distortionary price markup.
} 
the sticky inflation model of Fuhrer and Moore (1995b) and - to some extent - the habit formation model of Fuhrer (2000).

\subsection{Model Setup}

Aggregate supply is modeled by the expectational Phillips curve

$$
\pi_{t}=\varphi_{\pi} \mathrm{E}_{t} \pi_{t+1}+\left(1-\varphi_{\pi}\right) \pi_{t-1}+\alpha y_{t}+\varepsilon_{t}^{\pi},
$$

where $\pi_{t}$ is the rate of inflation (the log change in the price level between periods $t-1$ and $t$ ); $y_{t}$ is the output gap (the log deviation of real output from its natural level); and $\varepsilon_{t}^{\pi}$ is a white noise "cost-push" shock with variance $\sigma_{\pi}^{2}$. The parameter $0 \leq \varphi_{\pi} \leq 1$ determines the degree to which firms are forward-looking when setting their prices, and $\alpha>0$ is related to the degree of price rigidity (more price stickiness implies a lower value of $\alpha$ ). When $\varphi_{\pi}=1$ this is a standard "New-Keynesian" Phillips curve, which can be derived from several different models of staggered pricesetting (Roberts, 1995). The inclusion of inertia $\left(\varphi_{\pi}<1\right)$ is empirically motivated and can be interpreted as a proportion of firms using a naive rule (a rule of thumb) to forecast inflation (see Roberts, 1997; Galí and Gertler, 1999). ${ }^{12}$ With such inertia, inflation does not jump directly to equilibrium in response to shocks. Instead, policy efforts directed at altering inflation produce movements in real output (Ball, 1994).

Aggregate demand is represented by the IS curve

$$
y_{t}=\varphi_{y} \mathrm{E}_{t} y_{t+1}+\left(1-\varphi_{y}\right) y_{t-1}-\beta\left[i_{t}-\mathrm{E}_{t} \pi_{t+1}\right]+\varepsilon_{t}^{y},
$$

where $i_{t}$ is the nominal one-period interest rate, which is the instrument of monetary policy, and $\varepsilon_{t}^{y}$ is a white noise demand shock with variance $\sigma_{y}^{2}$. The parameter $\beta>0$ is the inverse of the intertemporal elasticity of substitution in consumption, and $0 \leq \varphi_{y} \leq 1$ determines the degree to which agents are forward-looking in their consumption decisions. When $\varphi_{y}=1$, equation (5) is a log-linear approximation of the Euler condition from a representative agent's consumption choice. The inclusion of the lagged output gap (with $\varphi_{y}<1$ ) can be due to habit formation, which leads to consumers smoothing both the level and the growth rate of consumption, making consumption an endogenously persistent variable (Fuhrer, 2000). The model

\footnotetext{
${ }^{12}$ Similar Phillips curve specifications, but with equal weights on expected and lagged inflation, can be obtained assuming that those prices that are not reoptimized in a given period are indexed to lagged inflation (as in Christiano et al., 2001) or that nominal wages are set in overlapping two-period contracts with an eye to the consequences for the relative real wage (as in Buiter and Jewitt, 1981, or Fuhrer and Moore, 1995a). In our baseline parameterization of the model we set $\varphi_{\pi}=0.5$, which is consistent with these alternative interpretations.
} 
Table 1: Baseline parameter values in stylized model

\begin{tabular}{lccc}
\hline \hline & Inflation & & Output gap \\
\hline$\varphi_{\pi}$ & 0.5 & $\varphi_{y}$ & 0.5 \\
$\alpha$ & 0.2 & $\beta$ & 0.1 \\
$\sigma_{\pi}^{2}$ & 1.0 & $\sigma_{y}^{2}$ & 1.0 \\
\hline
\end{tabular}

is closed by assuming that the central bank sets $i_{t}$ to minimize (1) under either precommitment or discretion.

To parameterize the model, we choose baseline parameter values that are similar to those estimated by Smets (2000) on annual euro area data for 1974-1998. ${ }^{13}$ We set the slope of the Phillips curve to $\alpha=0.2$ and the elasticity of output with respect to the real interest rate (the inverse of the intertemporal elasticity of substitution) to $\beta=0.1$. The degree of forward-looking behavior is notoriously difficult to estimate, and authors use any value ranging from 0 to 1 . We therefore choose baseline values of $\varphi_{\pi}=\varphi_{y}=0.5$. For simplicity, we set the variances of inflation and output shocks to unity: only the ratio of the two variances is important for our results, and this ratio is close to unity in Smets (2000). These parameter values are summarized in Table 1.

The policy preference parameters $\lambda$ and $\nu$ will play an important role in the analysis; for these we analyze combinations of $\lambda \in[0,2]$ and $\nu \in[0,1]$. These combinations seem to cover the plausible range, although empirical studies sometimes obtain larger values for $\nu$ (see, e.g., Dennis, 2001b; and Söderström et al., 2002). Finally, we set the discount factor to $\delta=0.99 .{ }^{14}$

Appendix A shows how to set up and solve the model using the algorithms developed by Dennis (2001a).

\subsection{The Stabilization Bias}

For an intuitive description of the stabilization bias, it is instructive to inspect the dynamic response of the economy to a one unit cost-push shock $\left(\varepsilon_{t}^{\pi}\right)$ under precommitment and discretion. These responses are shown in Figure 1 for the preference parameters $\lambda=0.5, \nu=0$, i.e., without interest rate smoothing. In both regimes, the shock leads to a period where inflation is above target. To dampen

\footnotetext{
${ }^{13}$ Estimates of $\alpha$ in the literature range from a low value of 0.024 (Rotemberg and Woodford, 1997) to a high value of 0.39 (Orphanides and Wieland, 2000). Empirical estimates of $\beta$ range from 0.02 (Gerlach and Smets, 1999) to 0.4 (Orphanides and Wieland, 2000).

${ }^{14}$ The results are not very sensitive to the discount rate.
} 
Figure 1: Impulse responses to cost-push shock in the stylized model

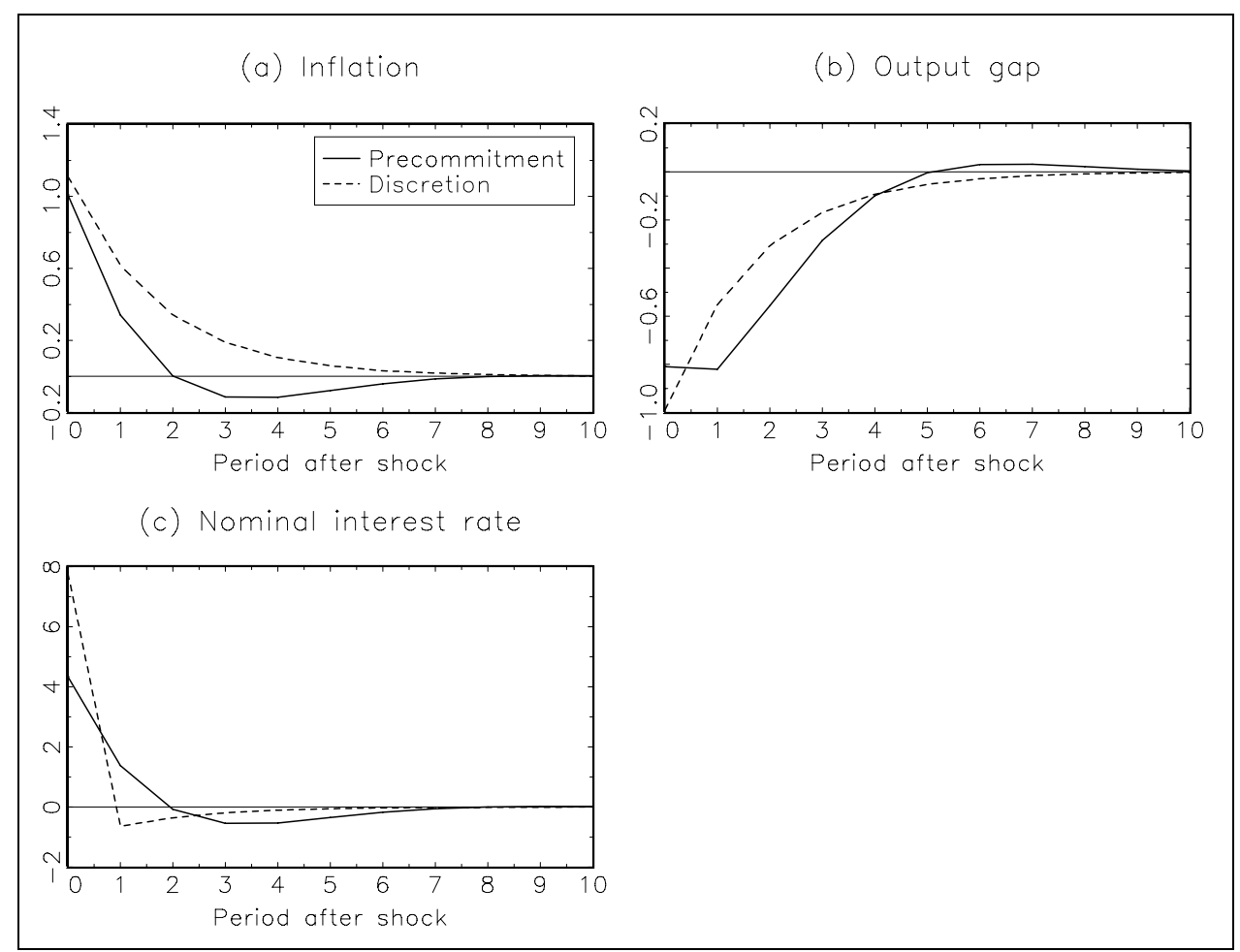

Note: Unit shock to $\varepsilon_{t}^{\pi}$. Baseline parameters, preferences are $(\lambda, \nu)=(0.5,0)$.

inflationary pressures the central bank must open up a negative output gap, and since $\lambda>0$ this is costly in terms of social welfare (i.e., there is a policy trade-off). Under precommitment the central bank can credibly promise to let the period of high inflation be followed by a period of inflation below target (by creating a more persistent negative output gap). This has a moderating effect on current inflation expectations and, therefore, also on current inflation. As a consequence, a smaller (but more persistent) policy tightening is needed to create the negative output gap.

Under discretion a promise to push inflation below target in the future is not credible (or time-consistent); once inflation is back on target, the central bank has an incentive to renege on its promises, because the period of deflation comes at a cost. Instead, the time-consistent policy response gradually brings inflation and the output gap back to target without any over-shooting. The result is a larger policy tightening, a higher (and more volatile) rate of inflation, and a slightly smaller (and less persistent) output gap.

These differences between precommitment and discretion are presented in Table 2 for nine different configurations of $(\lambda, \nu)$. The optimal policy under precommitment always entails lower volatility in inflation and the interest rate change, but a more volatile output gap. The resulting loss is therefore higher under discretion than 
Table 2: Unconditional variances and gain from precommitment in stylized model

\begin{tabular}{|c|c|c|c|c|c|c|c|c|c|}
\hline$\lambda$ & $\nu$ & Regime & $\operatorname{Var}(\pi)$ & $\operatorname{Var}(y)$ & $\operatorname{Var}(i)$ & $\operatorname{Var}(\Delta i)$ & Loss & $\Omega$ & $\hat{\pi}$ \\
\hline \multirow[t]{2}{*}{0.5} & 0.0 & Precomm. & 1.17 & 1.73 & 121.45 & 229.95 & 2.00 & 18.26 & 0.67 \\
\hline & & Discretion & 1.78 & 1.42 & 161.05 & 331.41 & 2.45 & & \\
\hline \multirow[t]{2}{*}{1.0} & 0.0 & Precomm. & 1.64 & 1.06 & 109.45 & 211.52 & 2.66 & 21.02 & 0.84 \\
\hline & & Discretion & 2.65 & 0.77 & 129.66 & 258.87 & 3.36 & & \\
\hline \multirow[t]{2}{*}{2.0} & 0.0 & Precomm. & 2.23 & 0.64 & 104.98 & 205.30 & 3.44 & 23.81 & 1.04 \\
\hline & & Discretion & 3.80 & 0.41 & 116.01 & 227.69 & 4.52 & & \\
\hline \multirow[t]{2}{*}{0.5} & 0.1 & Precomm. & 1.74 & 2.31 & 13.31 & 6.08 & 3.44 & 18.40 & 0.88 \\
\hline & & Discretion & 2.53 & 1.72 & 14.64 & 8.87 & 4.21 & & \\
\hline \multirow[t]{2}{*}{1.0} & 0.1 & Precomm. & 2.00 & 1.77 & 14.50 & 7.34 & 4.42 & 16.62 & 0.94 \\
\hline & & Discretion & 2.95 & 1.39 & 16.18 & 10.48 & 5.30 & & \\
\hline \multirow[t]{2}{*}{2.0} & 0.1 & Precomm. & 2.42 & 1.27 & 17.16 & 10.15 & 5.88 & 16.06 & 1.06 \\
\hline & & Discretion & 3.69 & 1.03 & 19.08 & 13.76 & 7.00 & & \\
\hline \multirow[t]{2}{*}{0.5} & 0.5 & Precomm. & 2.36 & 2.78 & 6.86 & 2.22 & 4.74 & 29.65 & 1.41 \\
\hline & & Discretion & 3.85 & 2.15 & 9.43 & 3.86 & 6.74 & & \\
\hline \multirow[t]{2}{*}{1.0} & 0.5 & Precomm. & 2.48 & 2.33 & 7.52 & 2.62 & 5.98 & 25.82 & 1.44 \\
\hline & & Discretion & 4.09 & 1.91 & 10.21 & 4.39 & 8.06 & & \\
\hline \multirow[t]{2}{*}{2.0} & 0.5 & Precomm. & 2.76 & 1.83 & 8.82 & 3.46 & 7.98 & 22.36 & 1.52 \\
\hline & & Discretion & 4.57 & 1.59 & 11.61 & 5.39 & 10.28 & & \\
\hline
\end{tabular}

under precommitment, and a central bank that is able to precommit to an optimal policy rule can lower the value of the loss function by 15-30\% relative to the optimal policy under discretion. ${ }^{15}$ The inflation equivalent varies between 0.67 and 1.52 , depending on central bank preferences. The inefficiency of discretionary policy is thus equivalent to a permanent deviation of inflation from target that is between $2 / 3$ and $11 / 2$ percentage points.

\footnotetext{
${ }^{15}$ The fact that the stabilization bias leads to inefficiently low volatility in output, but too volatile inflation and interest rate implies that the bias can be mitigated by appointing either a conservative central banker (with a small $\lambda$, see Svensson, 1997b; Clarida et al., 1999) or a central banker with a large preference for interest rate smoothing (Woodford, 1999b). Other mechanisms that have similar effects are a target for nominal income growth (Jensen, 2001), a price level target (Vestin, 2000), a multi-period inflation target (Nessén and Vestin, 2000), a target for the change in the output gap (Walsh, 2001), or a money growth target (Söderström, 2001).
} 
Figure 2: Inflation equivalent as Phillips curve parameters vary from baseline

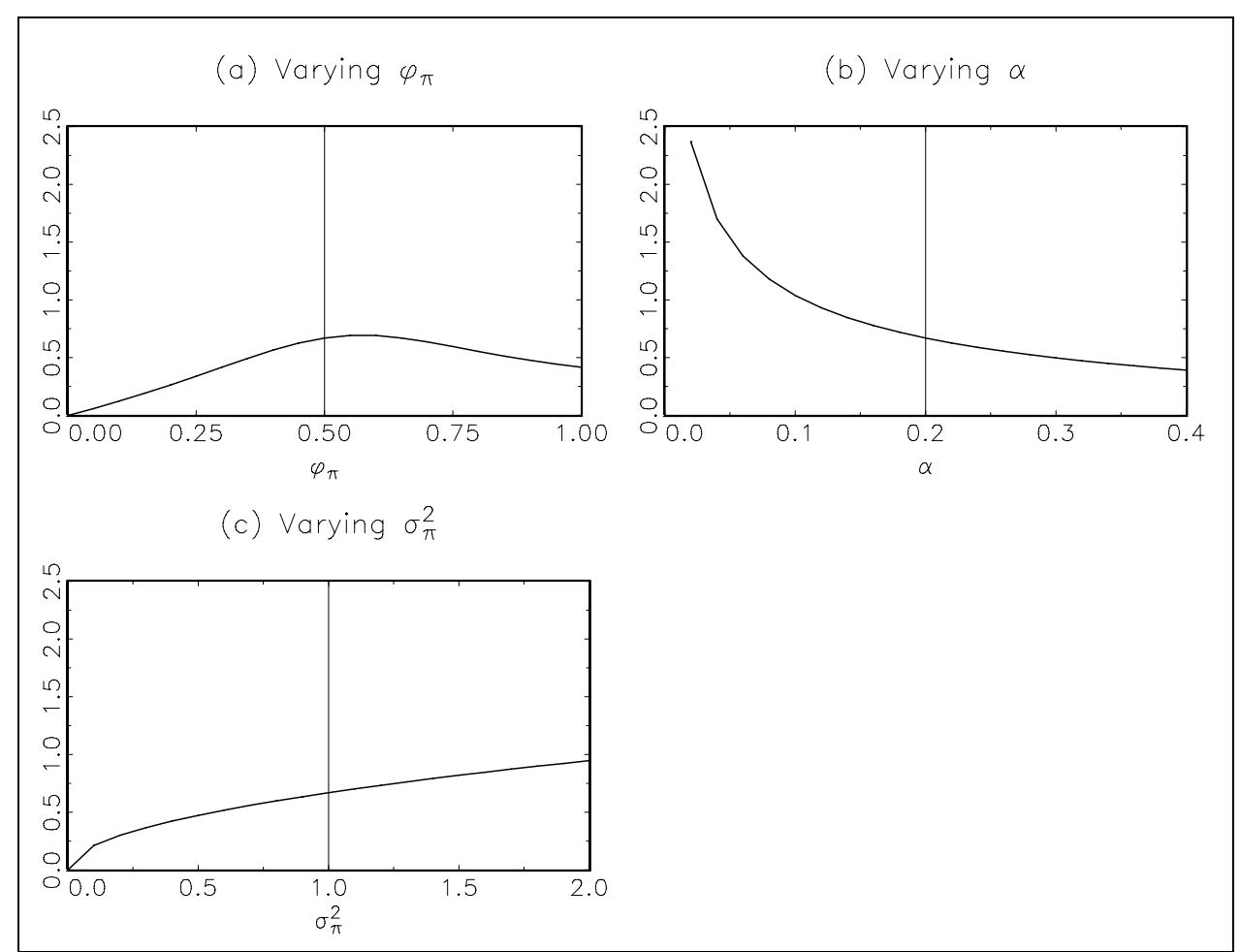

Note: Preferences are $(\lambda, \nu)=(0.5,0)$; vertical lines represent baseline values.

\subsection{Specification Issues}

Figure 2 shows how the inflation equivalent depends on the Phillips curve parameters in the case with $\lambda=0.5, \nu=0$. (The vertical lines represent the baseline value for the parameter in question.) Without interest rate smoothing, monetary policy can neutralize demand shocks, so these do not pose any policy trade-off. Consequently, the parameters in the IS equation do not affect the stabilization bias. With some degree of interest rate smoothing, or with transmission or expectations lags in the model, there will be a policy trade-off from demand shocks, and the IS parameters will affect the stabilization bias. However, these effects are small relative to those of the parameters in the Phillips curve, and the qualitative pattern in Figure 2 remains unaltered.

Panel $(a)$ of Figure 2 shows the effects of varying the importance of forwardlooking behavior in price setting, captured by the parameter $\varphi_{\pi}$. Since the mechanism behind the stabilization bias relies on the fact that private agents are forwardlooking in their behavior (in particular in price setting), one would expect the gain from precommitment to increase monotonically in the degree of forward-looking behavior. However, this turns out to be true only when backward-looking behavior 
dominates (when $\varphi_{\pi}$ is small): as the inflation process becomes primarily backwardlooking, the stabilization bias disappears. As $\varphi_{\pi}$ increases above 0.6 , so that forwardlooking expectations dominate, the stabilization bias becomes less severe. This is a result of the improved trade-off facing the central bank; as price-setters become predominantly forward-looking, it is easier to stabilize inflation, so the bias towards output stability becomes less serious. ${ }^{16}$

The parameter governing the slope of the Phillips curve, $\alpha$, which depends on the degree of price rigidity, is crucial in determining the trade-off between inflation and output variability. Thus, $\alpha$ has a large effect on the size of the stabilization bias: as the Phillips curve becomes flatter ( $\alpha$ falls), the trade-off becomes less favorable, so the stabilization bias becomes more severe. For more moderate slopes the effect on the stabilization bias is less pronounced. Finally, panel $(c)$ shows how the variance of cost-push shocks affects the stabilization bias: as cost-push shocks become more volatile, the inflation equivalent increases, again because inflation becomes more difficult to control.

A quite different specification issue concerns the introduction of lags in the model. In order to match the apparent gradual response of inflation and output to monetary policy shocks, it is common in empirical work to introduce additional lags into theoretical models. These can be either explicit lags in the transmission mechanism (e.g., Rudebusch and Svensson, 1999), or lags in the information set available to agents (assuming that agents make decisions one period earlier; see, e.g., Rotemberg and Woodford, 1997; Christiano et al., 2001). Since the estimated models examined in the following section also differ in this respect, it is of interest to see how the results from the stylized model depend on such choices.

\footnotetext{
${ }^{16}$ Some intuition for this result can be gained from the forward solution to the Phillips curve (4), given by$$
\pi_{t}=k \pi_{t-1}+\gamma \sum_{j=0}^{\infty} \theta^{j} \mathrm{E}_{t} y_{t+j}+\psi \varepsilon_{t}^{\pi}
$$

where $k=\left[1-\sqrt{1-4 \varphi_{\pi}\left(1-\varphi_{\pi}\right)}\right] /\left(2 \varphi_{\pi}\right) ; \psi=k /\left(1-\varphi_{\pi}\right) ; \gamma=\alpha \psi ;$ and $\theta=\varphi_{\pi} \psi$. Factors that lift $\psi$ raise the effective variance of the cost-push shock, which, as shown in Figure 2c, makes the stabilization bias worse. With $\gamma>0, \theta$ determines the importance of expected future output in the inflation process. As $\varphi_{\pi}$ increases from 0 to $0.5, \theta$ increases from 0 to 1 and $\psi$ increases from 1 to 2 , so expectations become more important and the effective variance of the supply shock increases; both effects exacerbate the stabilization bias. As $\varphi_{\pi}$ increases above 0.5 , however, $\theta$ remains constant at 1 , while $\psi$ falls back towards 1 . Thus, as $\varphi_{\pi}$ rises above 0.5 the forward-looking component of inflation is unaffected, but the effective variance of the supply shock declines. The combination of these two effects causes the hump-shaped response shown in Figure 2a. (We are grateful to Øystein Røisland for providing this intuition.)
} 
In our stylized framework, an "information lag" amounts to the specification

$$
\begin{aligned}
\pi_{t} & =\varphi_{\pi} \mathrm{E}_{t-1} \pi_{t+1}+\left(1-\varphi_{\pi}\right) \pi_{t-1}+\alpha \mathrm{E}_{t-1} y_{t}+\varepsilon_{t}^{\pi}, \\
y_{t} & =\varphi_{y} \mathrm{E}_{t-1} y_{t+1}+\left(1-\varphi_{y}\right) y_{t-1}-\beta\left[\mathrm{E}_{t-1} i_{t}-\mathrm{E}_{t-1} \pi_{t+1}\right]+\varepsilon_{t}^{y},
\end{aligned}
$$

a transmission lag leads to the specification

$$
\begin{aligned}
& \pi_{t}=\varphi_{\pi} \mathrm{E}_{t} \pi_{t+1}+\left(1-\varphi_{\pi}\right) \pi_{t-1}+\alpha y_{t-1}+\varepsilon_{t}^{\pi}, \\
& y_{t}=\varphi_{y} \mathrm{E}_{t} y_{t+1}+\left(1-\varphi_{y}\right) y_{t-1}-\beta\left[i_{t-1}-\mathrm{E}_{t-1} \pi_{t}\right]+\varepsilon_{t}^{y},
\end{aligned}
$$

while a combination of the two (as in Rudebusch, 2002) would have expectations dated $t-1$, but a lagged output gap and real interest rate. In the models including an information lag, monetary policy has no contemporaneous effects on the economy. If only a transmission lag is introduced, policy is allowed to have a contemporaneous effect on inflation and output via expectations.

Table 3 shows the percentage gain from precommitment and the inflation equivalent in the standard specification of the stylized model (in panel $(a)$ ) and when an information lag and/or transmission lag are introduced (panels $(b)-(d)$ ) for some configurations of $\lambda$ and $\nu$. Introducing a lag in the information set agents use to form expectations in panel $(b)$ has a large impact on the percentage gain from precommitment as well as on the inflation equivalent: the percentage gain decreases by $75 \%$ or $35 \%$ relative to the standard specification, depending on the weight on interest rate smoothing $(\nu)$, while the inflation equivalent decreases by $55 \%$ or $35 \%$. Introducing a lag in the transmission mechanism in panel $(c)$ decreases the percentage gain from precommitment by $70 \%$ or $40 \%$, again depending on $\nu$, while the inflation equivalent falls by $35 \%$ or $10 \%$. When combining the two lags in panel $(d)$, the effects reinforce each other: the percentage gain is $85 \%$ or $60 \%$ lower and the inflation equivalent decreases by $65 \%$ or $45 \%$ relative to the standard model. Consequently, a model's lag structure seems at least as important as its parameter values for determining the size of the stabilization bias.

\section{Estimated New-Keynesian Models}

To obtain empirical measures of the welfare gain from precommitment, this section analyzes three models of the U.S. economy that are estimated by Rudebusch (2002), Fuhrer and Moore (1995b) (FM), and Orphanides and Wieland (1998) (MSR). These models all contain forward-looking rational expectations and build in some form of 
Table 3: Gain from precommitment under different specifications of stylized model

\begin{tabular}{|c|c|c|c|c|c|}
\hline$\lambda$ & $\nu$ & $\begin{array}{c}\text { Loss under } \\
\text { precommitment }\end{array}$ & $\begin{array}{l}\text { Loss under } \\
\text { discretion }\end{array}$ & $\begin{array}{l}\text { \% Gain from } \\
\text { precommitment }\end{array}$ & $\begin{array}{c}\text { Inflation } \\
\text { equivalent }\end{array}$ \\
\hline \multicolumn{6}{|c|}{ (a) $\mathrm{E}_{t}$ expectations, no transmission lag } \\
\hline 0.5 & 0.0 & 2.00 & 2.45 & 18.26 & 0.67 \\
\hline 1.0 & 0.0 & 2.66 & 3.36 & 21.02 & 0.84 \\
\hline 0.5 & 0.1 & 3.44 & 4.21 & 18.40 & 0.88 \\
\hline 1.0 & 0.1 & 4.42 & 5.30 & 16.62 & 0.94 \\
\hline \multicolumn{6}{|c|}{ (b) $\mathrm{E}_{t-1}$ expectations, no transmission lag } \\
\hline 0.5 & 0.0 & 1.98 & 2.08 & 4.46 & 0.30 \\
\hline 1.0 & 0.0 & 2.64 & 2.79 & 5.38 & 0.39 \\
\hline 0.5 & 0.1 & 2.29 & 2.61 & 12.60 & 0.57 \\
\hline 1.0 & 0.1 & 3.01 & 3.37 & 10.72 & 0.60 \\
\hline \multicolumn{6}{|c|}{ (c) $\mathrm{E}_{t}$ expectations, 1 period transmission lag } \\
\hline 0.5 & 0.0 & 3.03 & 3.23 & 6.14 & 0.44 \\
\hline 1.0 & 0.0 & 3.98 & 4.26 & 6.69 & 0.53 \\
\hline 0.5 & 0.1 & 5.49 & 6.19 & 11.25 & 0.83 \\
\hline 1.0 & 0.1 & 6.63 & 7.38 & 10.12 & 0.86 \\
\hline \multicolumn{6}{|c|}{ (d) $\mathrm{E}_{t-1}$ expectations, 1 period transmission lag } \\
\hline 0.5 & 0.0 & 2.17 & 2.23 & 2.49 & 0.24 \\
\hline 1.0 & 0.0 & 2.84 & 2.92 & 2.92 & 0.29 \\
\hline 0.5 & 0.1 & 2.99 & 3.26 & 8.22 & 0.52 \\
\hline 1.0 & 0.1 & 3.71 & 3.98 & 6.84 & 0.52 \\
\hline
\end{tabular}

Note: In panel $(b)$, the model is unstable for $\nu=0$; instead we set $\nu=0.0001$. 
"sticky prices" or "sticky inflation." Moreover, each model falls under the general classification "New-Keynesian." But underlying these similarities are differences that will have important consequences for our subsequent analysis.

In each model the monetary policy instrument is a short-term nominal interest rate. The short-term nominal interest rate affects the economy directly in Rudebusch, but operates through the term structure in FM and MSR. Money balances do not enter any of the models but can instead be thought of as being demand determined through an "LM curve" that is redundant for our analysis. Each of the models employs an "output gap" formulation, with production subsumed into "potential output" rather than modeled through an explicit production function. In the MSR model the demand components are modeled separately with these components and then aggregated to form an output gap. The other two models contain equations explaining the output gap directly, with no role for individual demand components. All three models explicitly or implicitly accommodate habit persistence.

For FM and MSR, prices are set in conjunction with wages through a process of overlapping contracts in which firms and workers negotiate the nominal wage, bearing in mind what the nominal wage implies for expected real wages over the length of the contract (see Buiter and Jewitt, 1981). Rudebusch uses a Phillips curve with mixed expectations to model inflation directly. The nature of these Phillips curves and overlapping wage/price contracts are such that for each model the classical dichotomy holds among real and nominal variables in steady state.

Below, each model is described and analyzed in detail. Standardized shocks are applied, with the resulting impulse response functions graphed to reveal each model's dynamic properties. These impulse response functions are generated under both precommitment and discretion for the policy objective function parameters $\lambda=0.5, \nu=0.1$. For each model, we vary the parameters in the policy objective function: the weight on output stabilization $(\lambda)$ is varied between 0 and 2 , while the weight on interest rate smoothing $(\nu)$ is varied between 0 and 1 (both in 0.1 increments). ${ }^{17}$ Then, for each parameterization, the objective function is evaluated under both precommitment and discretion and the resulting percentage gain from precommitment and the inflation equivalent are calculated.

\footnotetext{
${ }^{17} \mathrm{We}$ also calculated results for $\lambda, \nu \in[0,5]$, and the qualitative results are very similar to those reported here.
} 


\subsection{Rudebusch (2002)}

The Rudebusch (2002) model is similar to the stylized model analyzed in Section 3, but with a more complicated lag structure. The model consists of two equations that, conditional upon monetary policy, summarize the dynamics of (annualized) inflation, $\pi_{t}$, the output gap, $y_{t}$, and the nominal federal funds rate, $i_{t}$ (the policy instrument):

$$
\begin{aligned}
y_{t} & =1.15 y_{t-1}-0.27 y_{t-2}-0.09\left[i_{t-1}-\mathrm{E}_{t-1} \bar{\pi}_{t+3}\right]+\varepsilon_{y, t}, \quad \sigma_{y}=0.833 \\
\pi_{t} & =0.29 \mathrm{E}_{t-1} \bar{\pi}_{t+3}+0.71\left[0.67 \pi_{t-1}-0.14 \pi_{t-2}+0.40 \pi_{t-3}+0.07 \pi_{t-4}\right] \\
& +0.13 y_{t-1}+\varepsilon_{\pi, t}, \quad \sigma_{\pi}=1.012
\end{aligned}
$$

where $\bar{\pi}_{t}=1 / 4 \sum_{j=0}^{3} \pi_{t-j}$ is annual inflation.

Equations (10) and (11) are empirically motivated with relatively little theoretical justification given for their dynamic structures. The long-run Phillips curve is vertical and the output gap is zero in steady state. The dynamics in the forwardlooking Phillips curve are attributed to generalized adjustment costs, while those in the IS curve are motivated by costly adjustment and habit formation. The key features of this model are that inflation and the output gap are highly persistent, that monetary policy affects the economy only with a lag, and that expectations are formed using period $t-1$ information. Notice, also, that the weight on expected future inflation in the Phillips curve, while consistent with much of the empirical literature, ${ }^{18}$ is small relative to many theory-based price setting specifications, and there is no forward-looking behavior in the IS curve. Naturally, the importance of the time-consistency problem is intertwined with the extent of forward-looking behavior (see Section 3). Demand and supply shocks are denoted $\varepsilon_{y, t}$ and $\varepsilon_{\pi, t}$, respectively.

Assume now that social welfare is given by equation (1), and consider the parameterization $\lambda=0.5, \nu=0.1{ }^{19}$ Figure 3 plots impulse response functions for inflation, output, and the nominal interest rate in response to unit demand and supply shocks under both precommitment and discretion. The most notable aspect of these impulse response functions is their similarity under precommitment and discretion; clearly the dynamics of the model are largely invariant to whether the policymaker can precommit or not. In response to supply shocks the interest rate is raised slightly more under precommitment than under discretion, and output falls

\footnotetext{
${ }^{18}$ See, e.g., Chadha et al. (1992), Roberts (1995, 1997), Fuhrer (1997c), or Lindé (2002).

${ }^{19}$ In what follows, we always set the discount factor to $\delta=0.99$.
} 
Figure 3: Impulse responses in the Rudebusch model

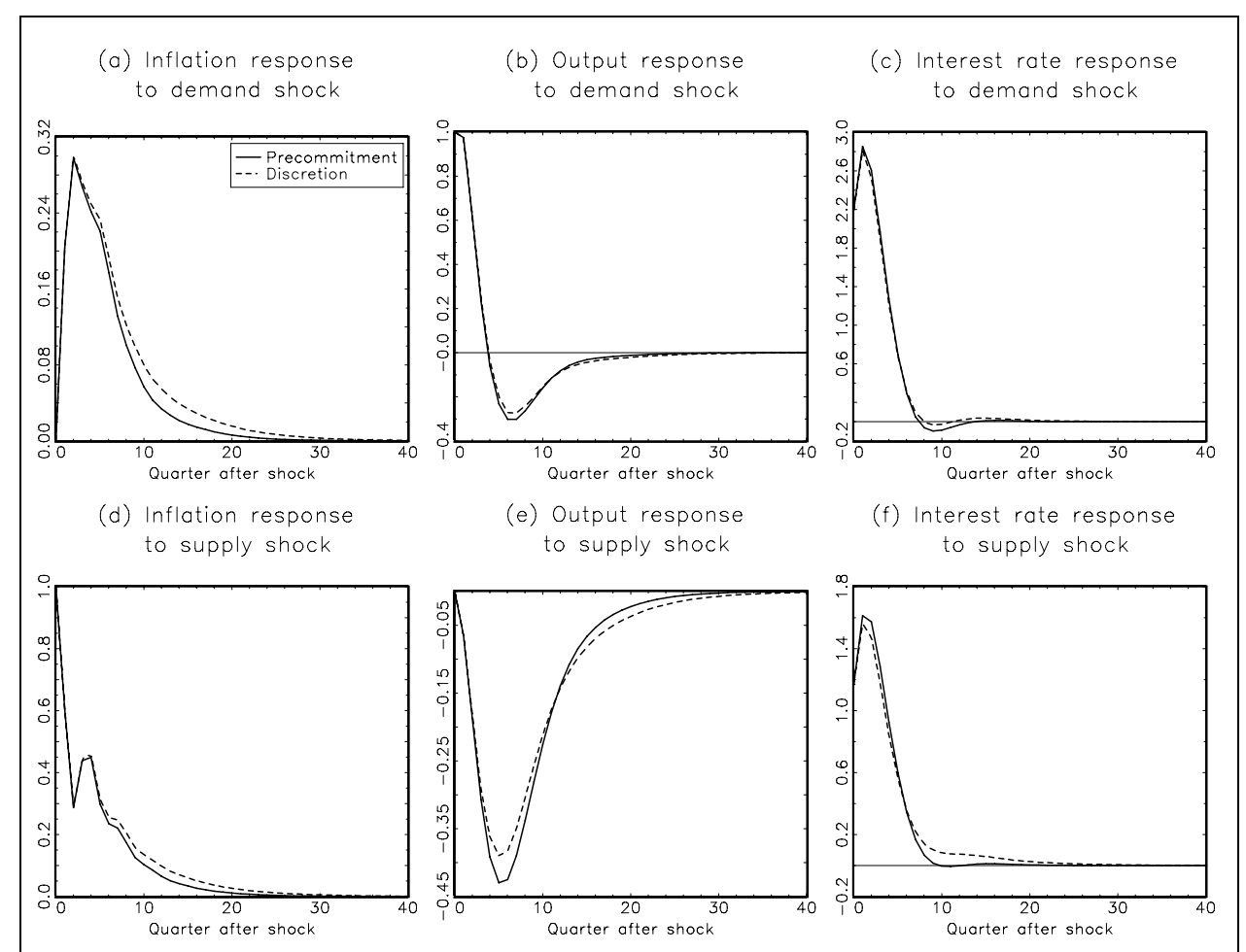

Note: The demand shock is a $1 \%$ impulse to $\varepsilon_{y, t}$, the supply shock is a $1 \%$ impulse to $\varepsilon_{\pi, t}$. Preferences are $(\lambda, \nu)=(0.5,0.1)$.

slightly more. For demand shocks, the precommitment and discretionary responses of output (and the interest rate) are almost indistinguishable from each other. The flipside of the (slightly) larger output response is that, with supply shocks, inflation returns to baseline slightly faster with precommitment than discretion, reflecting the benefits gained from promises kept.

Consistent with these small differences in impulse responses, Table 4 shows that the welfare gain associated with precommitment is relatively minor. For all parameterizations considered, the inflation equivalent is small and never more than 0.34 percentage points (when $\lambda=2, \nu=0$ ). For the parameterization used to generate the impulse responses the inflation equivalent is 0.15 percentage points.

\subsection{Fuhrer and Moore (1995b)}

The Fuhrer and Moore (1995b) model is well established and widely documented. It is somewhat more complicated than the Rudebusch model in that it contains an interest rate term structure equation and a system of equations that jointly govern the wage and price setting processes. On the demand side, the model contains an 
Table 4: Results from Rudebusch model

\begin{tabular}{cccccc}
\hline \hline$\lambda$ & $\nu$ & $\begin{array}{c}\text { Loss under } \\
\text { precommitment }\end{array}$ & $\begin{array}{c}\text { Loss under } \\
\text { discretion }\end{array}$ & $\begin{array}{c}\text { \% Gain from } \\
\text { precommitment }\end{array}$ & $\begin{array}{c}\text { Inflation } \\
\text { equivalent }\end{array}$ \\
\hline 0.0 & 0.0 & 1.29 & 1.29 & 0.28 & 0.06 \\
0.5 & 0.0 & 2.80 & 2.85 & 1.80 & 0.23 \\
1.0 & 0.0 & 3.70 & 3.78 & 2.05 & 0.28 \\
2.0 & 0.0 & 5.17 & 5.28 & 2.15 & 0.34 \\
& & & & & \\
0.0 & 0.1 & 2.74 & 2.75 & 0.41 & 0.11 \\
0.5 & 0.1 & 4.50 & 4.52 & 0.50 & 0.15 \\
1.0 & 0.1 & 5.84 & 5.88 & 0.57 & 0.18 \\
2.0 & 0.1 & 8.07 & 8.12 & 0.65 & 0.23 \\
& & & & & \\
0.0 & 0.5 & 4.04 & 4.06 & 0.39 & 0.13 \\
0.5 & 0.5 & 5.96 & 5.99 & 0.37 & 0.15 \\
1.0 & 0.5 & 7.57 & 7.60 & 0.37 & 0.17 \\
2.0 & 0.5 & 10.35 & 10.39 & 0.39 & 0.20 \\
& & & & & \\
0.0 & 1.0 & 4.96 & 4.98 & 0.37 & 0.14 \\
0.5 & 1.0 & 6.96 & 6.98 & 0.33 & 0.15 \\
1.0 & 1.0 & 8.69 & 8.72 & 0.32 & 0.17 \\
2.0 & 1.0 & 11.74 & 11.77 & 0.32 & 0.19 \\
\hline
\end{tabular}

output gap equation. The model equations are given by: ${ }^{20}$

$$
\begin{aligned}
y_{t} & =1.260 y_{t-1}-0.302 y_{t-2}-0.303 \rho_{t-1}+\varepsilon_{y, t}, \quad \sigma_{y}=0.603 \\
\rho_{t} & =\frac{40}{41} \mathrm{E}_{t} \rho_{t+1}+\frac{1}{41}\left[i_{t}-\mathrm{E}_{t} \pi_{t+1}\right] \\
p_{t} & =0.4195 w_{t}+0.3065 w_{t-1}+0.1935 w_{t-2}+0.0805 w_{t-3}, \\
\pi_{t} & =4\left(p_{t}-p_{t-1}\right) \\
v_{t} & =0.4195 \bar{w}_{t}+0.3065 \bar{w}_{t-1}+0.1935 \bar{w}_{t-2}+0.0805 \bar{w}_{t-3}, \\
\bar{w}_{t} & =\mathrm{E}_{t}\left[0.4195 v_{t}+0.3065 v_{t+1}+0.1935 v_{t+2}+0.0805 v_{t+3}\right] \\
& +0.001 \mathrm{E}_{t}\left[0.4195 y_{t}+0.3065 y_{t+1}+0.1935 y_{t+2}+0.0805 y_{t+3}\right] \\
& +\varepsilon_{p, t}, \quad \sigma_{p}=0.167
\end{aligned}
$$

where $\bar{w}_{t}=w_{t}-p_{t}$.

The policy instrument is the nominal federal funds rate, $i_{t}$. Movements in $i_{t}$ are transmitted along the term structure and affect the ten-year real Treasury bond rate, $\rho_{t}$. In turn ten-year bond yields influence the output gap, $y_{t}$, and the output gap affects the nominal wage rate, $w_{t}$, negotiated between workers and firms. Workers

\footnotetext{
${ }^{20}$ Parameter estimates for this model are taken from Fuhrer (1997a, Table II).
} 
negotiating today are unable to renegotiate their wage until four quarters have elapsed, and hence they must forecast what the demand for their labor will be over this period. ${ }^{21}$ Firms' demand for labor is driven by output, which reflects the overall level of demand in the economy. Consequently, higher output leads to higher nominal wages. Prices, $p_{t}$, are then set as a (constant) markup over the wage rates agreed to in existing contracts. The weights $f_{0}, \ldots, f_{3}$, which sum to one, reflect the proportion of wage contracts in force today that were negotiated this period and in the three previous quarters. Notice that the real wage $\bar{w}_{t}$ is not very sensitive to the output gap, which implies that the propagation of demand shocks into price/wage outcomes will be quite weak.

Key rigidities operate in the wage/price sector as the contract structure prevents wages from clearing the labor market. Instead, the labor market clears through labor working whatever hours firms demand. A further rigidity is introduced through the lag with which interest rates affect output. While the IS curve is highly inertial due to backward-looking elements that reflect adjustments costs and (implicit) habit formation, the inclusion of the long-term bond rate does introduce a forward-looking dimension.

Figure 4 shows how the Fuhrer-Moore model responds to demand and supply shocks where $\lambda=0.5$ and $\nu=0.1$. The demand shock is a unit increase in $\varepsilon_{y, t}$; the supply shock is a 0.25 increase in $\varepsilon_{p, t}$, which (ceteris paribus) implies a $1 \%$ shock to annualized inflation, $\pi_{t}$. Inflation is relatively impervious to the demand shock, a feature that holds under both precommitment and discretion. The small inflation response is, of course, due to the weak sensitivity of the real wage to output. With discretion, interest rates are raised considerably less in response to demand shocks than they are under precommitment. However, the opposite is true for supply shocks, for which discretion produces a more aggressive policy intervention. At the same time, under precommitment, output losses are greater and inflation returns to steady state more quickly.

The welfare gain from precommitment in Table 5 is largest for small weights on interest rate smoothing and large weights on output stabilization. For most of the parameter configurations considered the inflation equivalent is between 1.4 and 3.6 percentage points. For the objective function parameters used in Figure 4 the inflation equivalent is 1.55 percentage points.

\footnotetext{
${ }^{21}$ A relatively common simplification to this contracting framework is to assume two-period rather than four-period contracts. The advantage of two-period contracts is that it is possible to solve the wage/price sector of the model for an explicit Phillips curve (see Roberts, 1997).
} 
Table 5: Results from Fuhrer-Moore model

\begin{tabular}{cccccc}
\hline \hline$\lambda$ & $\nu$ & $\begin{array}{c}\text { Loss under } \\
\text { precommitment }\end{array}$ & $\begin{array}{c}\text { Loss under } \\
\text { discretion }\end{array}$ & $\begin{array}{c}\text { \% Gain from } \\
\text { precommitment }\end{array}$ & $\begin{array}{c}\text { Inflation } \\
\text { equivalent }\end{array}$ \\
\hline 0.0 & 0.0 & 0.69 & 0.81 & 14.08 & 0.34 \\
0.5 & 0.0 & 9.12 & 17.05 & 46.52 & 2.82 \\
1.0 & 0.0 & 10.94 & 21.14 & 48.27 & 3.19 \\
2.0 & 0.0 & 13.18 & 26.14 & 49.60 & 3.60 \\
& & & & & \\
0.0 & 0.1 & 3.72 & 4.51 & 17.65 & 0.89 \\
0.5 & 0.1 & 9.83 & 12.22 & 19.58 & 1.55 \\
1.0 & 0.1 & 12.14 & 15.80 & 23.18 & 1.91 \\
2.0 & 0.1 & 15.26 & 20.74 & 26.43 & 2.34 \\
& & & & & \\
0.0 & 0.5 & 4.47 & 5.54 & 19.32 & 1.03 \\
0.5 & 0.5 & 10.12 & 12.17 & 16.81 & 1.43 \\
1.0 & 0.5 & 12.59 & 15.67 & 19.66 & 1.76 \\
2.0 & 0.5 & 16.02 & 20.68 & 22.52 & 2.16 \\
& & & & & \\
0.0 & 1.0 & 4.85 & 6.09 & 20.46 & 1.12 \\
0.5 & 1.0 & 10.30 & 12.29 & 16.20 & 1.41 \\
1.0 & 1.0 & 12.85 & 15.77 & 18.55 & 1.71 \\
2.0 & 1.0 & 16.44 & 20.83 & 21.08 & 2.10 \\
\hline
\end{tabular}

Note: The model is unstable when $\lambda=\nu=0$. Instead we set $\lambda=\nu=10^{-7}$. 
Figure 4: Impulse responses in the Fuhrer-Moore model

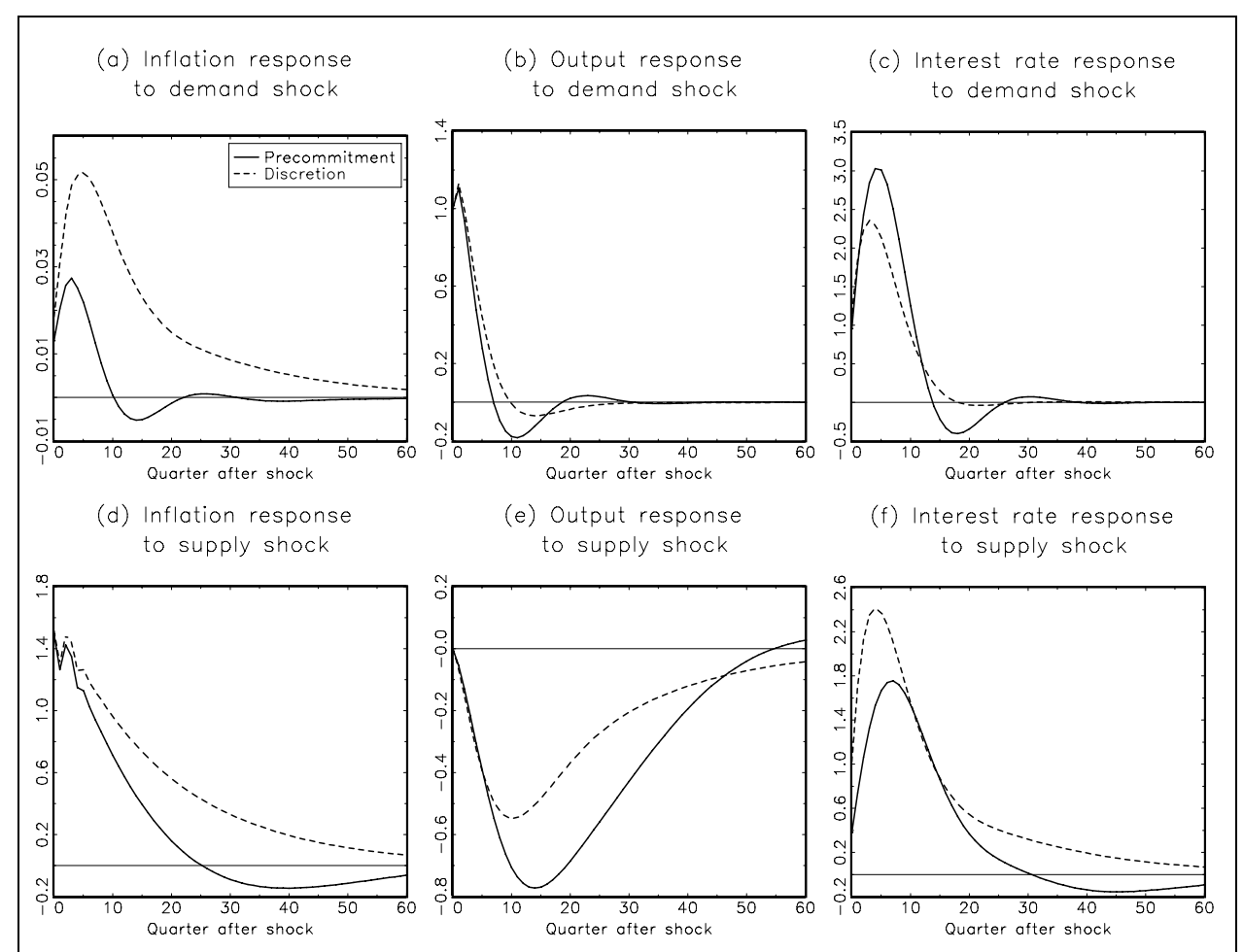

Note: The demand shock is a $1 \%$ impulse to $\varepsilon_{y, t}$, the supply shock is a $0.25 \%$ impulse to $\varepsilon_{p, t}$. Preferences are $(\lambda, \nu)=(0.5,0.1)$.

\subsection{Orphanides and Wieland (1998)}

The MSR model of Orphanides and Wieland (1998) shares several features with Fuhrer and Moore (1995b). Both MSR and FM employ overlapping relative real wage contracts and both models allow for bonds with different maturities. The two models differ most in their approach to modeling aggregate demand: MSR models the components of aggregate demand separately and then aggregates these components using the national accounts identity. Thus the output gap, $y_{t}$, is the sum of (the ratios to potential output of) consumption, $c_{t}$, fixed investment, $f i_{t}$, inventory investment, $i i_{t}$, net exports, $n x_{t}$, and government expenditure, $g_{t}$. Consumption depends on lagged consumption (through habit formation), permanent income, $y_{t}^{p}$, (approximately the perpetuity value of discounted expected future income), and long-term real interest rates, $r_{t}^{l}$. Fixed investment and inventory investment are modeled using accelerator mechanisms; long-term real interest rates also influence fixed investment. Net exports depend on domestic demand, $y_{t}$, and world demand, $y_{t}^{w}$, and on the real exchange rate, $e_{t}{ }^{22}$ Long-term real interest rates (the yield on a

\footnotetext{
${ }^{22}$ World demand and the real exchange rate are not modeled. Consequently, during simulations we condition on these two variables. Our approach differs slightly from Levin et al. (1999), who
} 
two-year bond) are related to the nominal return on short-term bonds, $i_{t}$, adjusted for expected future inflation through the pure expectations theory. The short-term nominal interest rate serves as the monetary policy instrument. Thus the model is given by ${ }^{23}$

$$
\begin{aligned}
y_{t} & =c_{t}+f i_{t}+i i_{t}+n x_{t}+g_{t} \\
c_{t} & =0.665 c_{t-1}+0.286 y_{t}^{p}-0.102 r_{t}^{l}+\varepsilon_{c, t}, \quad \sigma_{c}=0.356 \\
y_{t}^{p} & =\frac{1-0.9}{1-0.9^{9}} \mathrm{E}_{t} \sum_{j=0}^{8} 0.9^{j} y_{t+j}, \\
f i_{t} & =0.988 f i_{t-1}+0.171 f i_{t-2}-0.169 f i_{t-3}+0.134 y_{t}-0.050 y_{t-1} \\
& -0.128 y_{t-2}-0.033 r_{t}^{l}+\varepsilon_{f i, t}, \quad \sigma_{f i}=0.240, \\
i i_{t} & =0.324 i i_{t-1}+0.032 i i_{t-2}+0.168 i i_{t-3}+0.116 y_{t}+0.187 y_{t-1} \\
& -0.286 y_{t-2}+\varepsilon_{i i, t}, \quad \sigma_{i i}=0.350 \\
n x_{t} & =0.803 n x_{t-1}-0.050 y_{t}+\varepsilon_{n x, t}, \quad \sigma_{n x}=0.206 \\
g_{t} & =0.982 g_{t-1}+\varepsilon_{g, t}, \quad \sigma_{g}=0.180, \\
r_{t}^{l} & =\frac{1}{8} \mathrm{E}_{t} \sum_{j=0}^{7}\left[i_{t+j}-\pi_{t+j+1}\right] \\
p_{t} & =0.37045 w_{t}+0.29015 w_{t-1}+0.20985 w_{t-2}+0.12955 w_{t-3}, \\
\pi_{t} & =4\left(p_{t}-p_{t-1}\right) \\
v_{t} & =0.37045 \bar{w}_{t}+0.29015 \bar{w}_{t-1}+0.20985 \bar{w}_{t-2}+0.12955 \bar{w}_{t-3}, \\
\bar{w}_{t} & =\mathrm{E}_{t}\left[0.37045 v_{t}+0.29015 v_{t+1}+0.20985 v_{t+2}+0.12955 v_{t+3}\right] \\
& +0.0055 \mathrm{E}_{t}\left[0.37045 y_{t}+0.29015 y_{t+1}+0.20985 y_{t+2}+0.12955 y_{t+3}\right] \\
& +\varepsilon_{p, t}, \quad \sigma_{p}=0.167,
\end{aligned}
$$

where $\bar{w}_{t}=w_{t}-p_{t}$.

Monetary policy operates through multiple channels. Increases in short-term interest rates are propagated along the term structure through the expectations theory, which increases long-term interest rates. Higher long-term interest rates adversely affect firms' investment decisions (lowering fixed investment) and households' consumption/savings decision (lowering current period consumption relative

condition on net exports itself when simulating the MSR model.

${ }^{23}$ Estimates of the model's parameters are taken from Orphanides and Wieland (1998) and Fuhrer (1997b). Note that there are a couple of typos in Orphanides and Wieland (1998): the long-term nominal interest rate in their equation (2) should be multiplied by $1 / 8$ and the sum should be from 0 to 7 . The inflation rate is the annualized quarterly rate, so the expected rate of inflation in the long-term real rate in their equation (3) should also be multiplied by $1 / 8$. 
Figure 5: Impulse responses in the MSR model

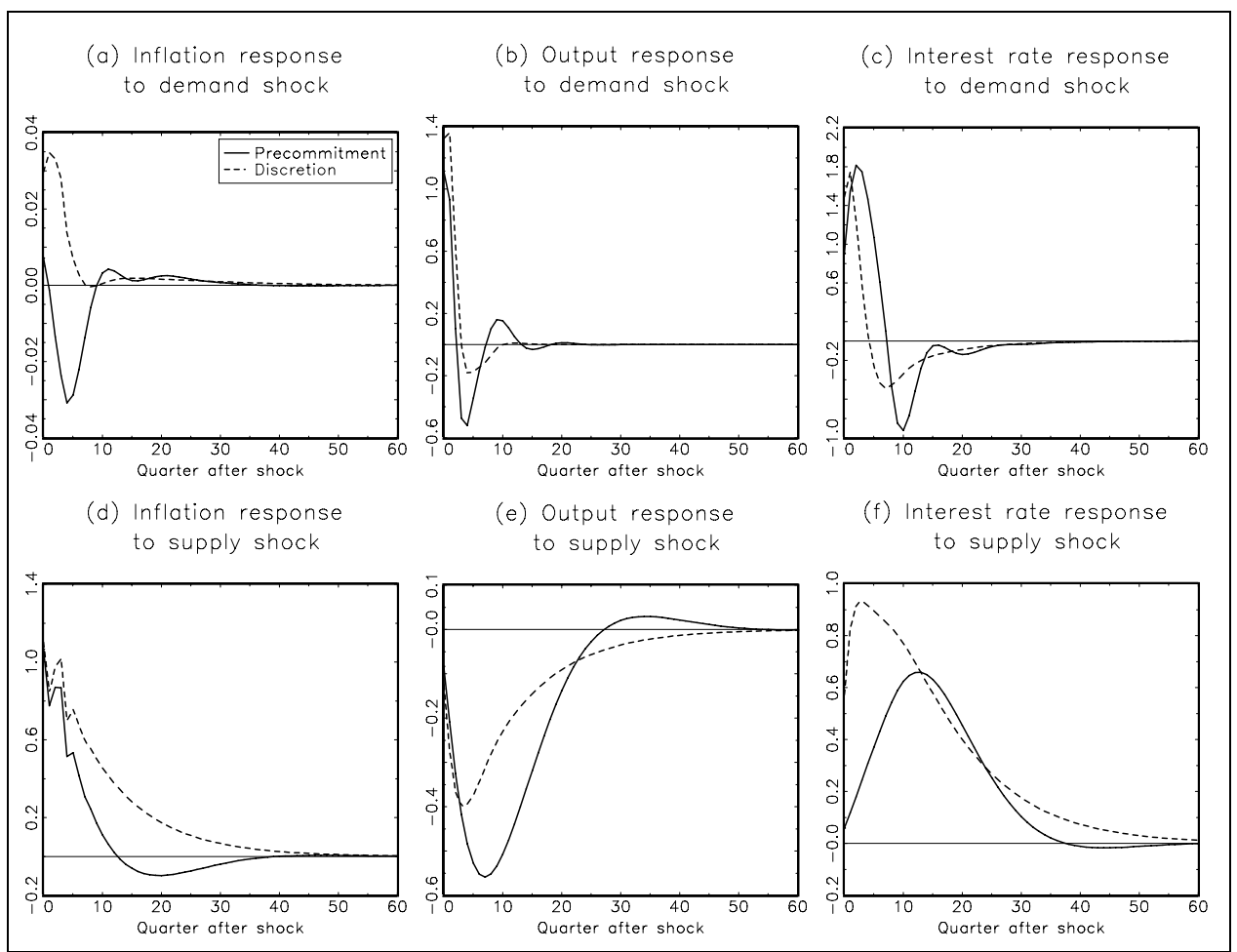

Note: The demand shock is a $1 \%$ impulse to $\varepsilon_{c, t}$, the supply shock is a $0.25 \%$ impulse to $\varepsilon_{p, t}$. Preferences are $(\lambda, \nu)=(0.5,0.1)$.

to future consumption). Falls in inventory investment and consumption reduce aggregate demand, which tempers the wage rate negotiated between workers and firms. Monetary policy's impact is propagated over time through habit formation, through accelerator mechanisms operating on investment, and through wage contracts.

To examine the model's dynamic responses to shocks we apply a unit shock to the consumption equation, $\varepsilon_{c, t}$, as the demand shock and a 0.25 impulse to $\varepsilon_{p, t}$ as the supply shock. The model's disaggregated approach on the demand side prevents us from applying a shock to aggregate demand directly, as we did previously. The impulse responses are shown in Figure 5.

In terms of the supply shock, the rise in inflation is considerably more persistent under discretion than it is under precommitment. Moreover, under discretion interest rates rise a lot more, but entail less effect on output than equivalent interest rate rises under precommitment. Clearly, a given movement in interest rates has a much more powerful effect on the economy under precommitment than it does under discretion. Demand shocks have very little impact on inflation. This is true whether policymakers can precommit or not and is a consequence of the low sensitivity of real wages to the output gap. Under discretion, the demand shock's impact leads 
Table 6: Results from MSR model

\begin{tabular}{cccccc}
\hline \hline$\lambda$ & $\nu$ & $\begin{array}{c}\text { Loss under } \\
\text { precommitment }\end{array}$ & $\begin{array}{c}\text { Loss under } \\
\text { discretion }\end{array}$ & $\begin{array}{c}\text { \% Gain from } \\
\text { precommitment }\end{array}$ & $\begin{array}{c}\text { Inflation } \\
\text { equivalent }\end{array}$ \\
\hline 0.0 & 0.0 & 0.45 & 0.57 & 21.60 & 0.35 \\
0.5 & 0.0 & 2.70 & 4.42 & 38.94 & 1.31 \\
1.0 & 0.0 & 3.32 & 5.82 & 42.94 & 1.58 \\
2.0 & 0.0 & 4.07 & 7.61 & 46.50 & 1.88 \\
& & & & & \\
0.0 & 0.1 & 0.74 & 1.02 & 27.75 & 0.53 \\
0.5 & 0.1 & 3.06 & 4.23 & 27.57 & 1.08 \\
1.0 & 0.1 & 3.98 & 5.77 & 30.94 & 1.34 \\
2.0 & 0.1 & 5.29 & 7.99 & 33.77 & 1.64 \\
& & & & & \\
0.0 & 0.5 & 0.99 & 1.41 & 30.00 & 0.65 \\
0.5 & 0.5 & 3.25 & 4.37 & 25.63 & 1.06 \\
1.0 & 0.5 & 4.32 & 6.05 & 28.70 & 1.32 \\
2.0 & 0.5 & 5.91 & 8.61 & 31.39 & 1.64 \\
& & & & & 0.72 \\
0.0 & 1.0 & 1.13 & 1.65 & 31.20 & 1.07 \\
0.5 & 1.0 & 3.35 & 4.49 & 25.33 & 1.66 \\
1.0 & 1.0 & 4.49 & 6.24 & 28.07 & 30.63 \\
2.0 & 1.0 & 6.21 & 8.96 & & 3.65 \\
\hline
\end{tabular}

Note: The model is unstable when $\lambda=0$ or $\nu=0$. Instead we set $\lambda=0.0013, \nu=0.001$.

to a greater output rise, but to a smaller interest rate response.

The overall profile of the welfare gain in Table 6 is similar to that for the FM model, although the inflation equivalent is typically a bit smaller. Under the benchmark preference parameters the inflation equivalent is 1.08 percentage points; for most parameter configurations, the inflation equivalent is between 1 and 2 percentage points.

\subsection{Assessing the Results}

A result that is robust across all three models is that the stabilization bias becomes worse, and the inflation equivalent becomes larger, as $\lambda$ increases. (This is also the case in the stylized model, see Table 2.) Thus as policymakers place greater weight on stabilizing output, precommitment takes on greater importance. Stabilization bias reflects the fact, that when policymakers cannot precommit, their behavior leads to over-stabilized output, at the cost of greater inflation variability. Thus, discretion produces an unfavorable trade-off between the variance of inflation and the variance of output relative to precommitment, which means that at the margin efforts to reduce output volatility come at a greater cost in terms of inflation variability. It is 
this unfavorable trade-off between the variances of output and inflation that causes the stabilization bias, and the inflation equivalent, to increase with $\lambda$.

Furthermore, for all three estimated models (but not the stylized model), the inflation equivalent tends to decline in $\nu$ (as long as $\lambda>0$ ). Greater weight on interest rate smoothing makes it costly for policymakers to undertake the large policy interventions that may be needed to offset shocks. Because stabilization bias is a consequence of policymakers' responding inefficiently to shocks, and greater weight on interest rate smoothing leads to policymakers being less concerned about offsetting shocks, the inflation equivalent tends to fall with $\nu$.

The results for the Rudebusch model stand out as being very different from the other two models. For the Rudebusch model the welfare gain from precommitment is very small: the inflation equivalent is below 0.34 percentage points for all values of $\lambda$ and $\nu$ considered, and much less than this for most parameter configurations. For the other two models, the minimum inflation equivalent, for any parameterization, is around 0.35 percentage points.

Structurally, the Rudebusch model is different from the other models in several respects. First, expected future inflation plays a smaller role in the Phillips curve than for the other models; the weight on expected future inflation is just 0.29. In contrast, a 0.5 weight is placed on expectations of future inflation in FM and MSR. Second, expectations in the Rudebusch model are formed using information available in period $t-1$, whereas in the other models expectations are formed using period $t$ information. Third, in the Rudebusch model monetary policy only affects output and inflation with a one-period lag. In FM there is a one-period lag for monetary policy to affect output, but not inflation, while policy's impact is contemporaneous in MSR.

To understand why these features of the Rudebusch model matter so much for the size of the welfare gain, it is useful to recall the lessons from Section 3. There we showed that the welfare gain from precommitment is small when the weight on expected future inflation is low in the Phillips curve. The reason for this is simply that policymakers' reneging on commitments is less important where firms and households do not take these commitments into account in their pricing and consumption decisions. But this is not the whole story. Section 3 also demonstrated that a principal benefit to precommitment is that it helps policymakers efficiently offset shocks as they occur. When monetary policy affects the economy with a lag it is more difficult for policymakers to offset, or mitigate, the impact of shocks.

Finally, Section 3 showed that the dating on the information set used to form 
expectations is crucial for determining how much precommitment outperforms discretion. When expectations are formed using period $t-1$ information, as in the Rudebusch model, expectations are predetermined with respect to current policy decisions, so movements in interest rates today do not immediately influence agents' expectations about the future. This is important because the major advantage to being able to precommit is that credible policy announcements give policymakers influence over agents' expectations. But if expectations are predetermined with respect to current policy decisions, then this limits the policymaker's ability to influence expectations through credible commitments. It is these three features of the Rudebusch model that make the welfare gain from precommitment so small.

Turning to the FM and MSR models, the welfare gain from precommitment is surprisingly large. For our benchmark policy regime $(\lambda=0.5, \nu=0.1)$ the inflation equivalent is 1.55 percentage points in the FM model and 1.08 percentage points in the MSR model. Recall that the steady state to which the economy converges is the same under precommitment and discretion; thus the welfare difference arises entirely from the path the economy takes in response to shocks. Because the future is discounted, the most important determinant of the welfare gain is the economy's response to shocks soon after their impact; hence, the efficiency with which policymakers can counter shocks is critical for welfare.

Tables 4-6 clearly show that the size of the stabilization bias and the welfare gain from precommitment depend on much more than just the degree of forward-looking behavior in a model. Information sets, control lags, the degree of forward-looking behavior, and interactions between monetary policy and the nature of wage contracts, price rigidities, and monopolistic competition all have important implications for the stabilization bias. Moreover, for realistic policy regimes and for quite plausible, data-consistent, macroeconomic models, the welfare gain from precommitment can be large.

\section{Conclusions}

In the absence of precommitment mechanisms, a stabilization bias is inevitable in a large class of dynamic forward-looking rational expectations models. But whether the stabilization bias and the welfare gain from precommitment are large or small is an empirical issue that can be resolved only using data-consistent models. Establishing that the welfare gain from precommitment is large is an important first step in justifying institutional reforms that facilitate commitment, for these reforms 
come at a cost. One of the main contributions of this paper is that it quantifies the benefits to precommitment using models that are data-consistent. Thus the welfare gains identified in this paper are those that might reasonably be attained in actual economies.

Given that forward-looking expectations are necessary for the stabilization bias, it is perhaps natural to anticipate that the more forward-looking behavior a model is, the worse the stabilization bias will be. However, using a popular macroeconomic model we show that this intuitive mechanism does not hold with respect to the forward-looking term in an expectations-augmented Phillips curve. Furthermore, forward-looking behavior is not the only factor that affects the welfare gain from precommitment. Another important factor is whether monetary policy affects the economy with a lag. Where there are a transmission lags, the gain from precommitment is smaller because policymakers are less able to use credible commitments to help preempt shocks. Similarly, where private agents form expectations using a dated information set, the welfare gain from precommitment is also reduced. This occurs because agents' expectations do not fully reflect the policymaker's most recent decisions about policy, or their likely impact on future outcomes. The importance of transmission lags and the dating on the information set used to form expectations come to the fore in the Rudebusch (2002) model, for which both factors are present and the welfare gain from precommitment is minuscule.

The monetary policy regime itself is also important; a policy regime that emphasizes output stabilization over inflation stabilization leads to the increasing importance of precommitment for welfare. But this gain from precommitment tends to decline as policymakers become more concerned with interest rate smoothing. Clearly there are important interactions between wage/price rigidities and the monetary policy regime that are difficult to appreciate fully without closed-form analytic solutions. But obtaining closed-form solutions is all but impossible for anything other than the simplest dynamic models, and such solutions are not available for the estimated models examined in this paper.

For each of the three estimated models examined in Section 4, a large number of different policy objective function parameterizations were considered. These parameterizations seem to cover the plausible range. For two of the three models the welfare gains from precommitment appear quite large; only in the Rudebusch model is the welfare gain from precommitment small. Across the three models and various policy regimes, the inflation equivalent ranges anywhere between 0.05 and 3.6 percentage points. Under the benchmark parameterization focused on in Section 4 , 
the inflation equivalent is $0.15,1.55$, and 1.08 percentage points for the Rudebusch, FM, and MSR models respectively. Thus, while the FM and MSR models broadly agree that the welfare gain from precommitment is important, the results from the Rudebusch model give reason to pause. Further econometric analysis directed at identifying control lags, the structure of information sets, and policy regimes appears critical for establishing how important precommitment is for welfare and economic outcomes. 


\section{A Solving the Models}

This Appendix describes how the models in Sections 3 and 4 are solved. The numerical algorithms that we use to solve for the precommitment and discretionary solutions are derived in Dennis (2001a). These algorithms require that the optimization constraints be written in structural form:

$$
\mathbf{A}_{0} \mathbf{y}_{t}=\mathbf{A}_{1} \mathbf{y}_{t-1}+\mathbf{A}_{2} \mathrm{E}_{t} \mathbf{y}_{t+1}+\mathbf{A}_{3} \mathbf{x}_{t}+\mathbf{A}_{4} \mathrm{E}_{t} \mathbf{x}_{t+1}+\mathbf{A}_{5} \mathbf{v}_{t}, \quad \mathbf{v}_{t} \sim \operatorname{iid}[\mathbf{0}, \mathbf{\Sigma}]
$$

and that the policy objective (loss) function be a discounted quadratic:

$$
\operatorname{Loss}[t, \infty]=(1-\delta) \mathrm{E}_{t} \sum_{j=0}^{\infty} \delta^{j}\left[\mathbf{y}_{t+j}^{\prime} \mathbf{W} \mathbf{y}_{t+j}+\mathbf{x}_{t+j}^{\prime} \mathbf{Q} \mathbf{x}_{t+j}\right], \quad 0<\delta<1,
$$

where $\mathbf{y}_{t}$ is a vector of endogenous variables, $\mathbf{x}_{t}$ a vector of policy instruments, and $\mathbf{v}_{t}$ a vector of innovations. Terms where $\mathbf{y}_{t}$ and $\mathbf{x}_{t}$ interact can be included in the quadratic loss function, but this provides no extra generality as interaction terms can always be accommodated through the choice of $\mathbf{y}_{t}$. Once the optimization problem is written in terms of equations (A1) and (A2) the methods in Dennis (2001a) can be applied directly. The algorithms solve for feedback rules, unconditional variances, and impulse responses, and they evaluate the loss function at the optimum. In the remainder of this Appendix we use the model analyzed in Section 3 to show how to write the model in terms of equations (A1) and (A2), and we present its solution under precommitment and discretion. The models examined in Section 4 are solved similarly.

The model is given by the equations

$$
\begin{aligned}
\pi_{t} & =\varphi_{\pi} \mathrm{E}_{t} \pi_{t+1}+\left(1-\varphi_{\pi}\right) \pi_{t-1}+\alpha y_{t}+\varepsilon_{t}^{\pi}, \\
y_{t} & =\varphi_{y} \mathrm{E}_{t} y_{t+1}+\left(1-\varphi_{y}\right) y_{t-1}-\beta\left[i_{t}-\mathrm{E}_{t} \pi_{t+1}\right]+\varepsilon_{t}^{y},
\end{aligned}
$$

and the policy objective function

$$
\operatorname{Loss}[t, \infty]=(1-\delta) \mathrm{E}_{t} \sum_{j=0}^{\infty} \delta^{j}\left[\pi_{t+j}^{2}+\lambda y_{t+j}^{2}+\nu\left(i_{t+j}-i_{t+j-1}\right)^{2}\right]
$$

for which $\lambda, \nu \geq 0$. Defining the vectors

$$
\begin{aligned}
& \mathbf{y}_{t}=\left[\begin{array}{llll}
\pi_{t} & y_{t} & i_{t} & \Delta i_{t}
\end{array}\right]^{\prime}, \\
& \mathbf{x}_{t}=\left[\begin{array}{l}
i_{t}
\end{array}\right] \\
& \mathbf{v}_{t}=\left[\begin{array}{ll}
\varepsilon_{t}^{\pi} & \varepsilon_{t}^{y}
\end{array}\right]^{\prime},
\end{aligned}
$$


the model is in the required form, where the structural form parameter matrices are

$$
\begin{aligned}
& \mathbf{A}_{0}=\left[\begin{array}{cccc}
1 & -\alpha & 0 & 0 \\
0 & 1 & 0 & 0 \\
0 & 0 & 1 & 0 \\
0 & 0 & 0 & 1
\end{array}\right] \\
& \mathbf{A}_{1}=\left[\begin{array}{cccc}
1-\varphi_{\pi} & 0 & 0 & 0 \\
0 & 1-\varphi_{y} & 0 & 0 \\
0 & 0 & 0 & 0 \\
0 & 0 & -1 & 0
\end{array}\right] \text {, } \\
& \mathbf{A}_{2}=\left[\begin{array}{cccc}
\varphi_{\pi} & 0 & 0 & 0 \\
\beta & \varphi_{y} & 0 & 0 \\
0 & 0 & 0 & 0 \\
0 & 0 & 0 & 0
\end{array}\right] \\
& \mathbf{A}_{3}=\left[\begin{array}{llll}
0 & -\beta & 1 & 1
\end{array}\right]^{\prime}, \\
& \mathbf{A}_{4}=\left[\mathbf{0}_{4 \times 1}\right] \text {, } \\
& \mathbf{A}_{5}=\left[\begin{array}{llll}
1 & 0 & 0 & 0 \\
0 & 1 & 0 & 0
\end{array}\right]^{\prime} \text {. }
\end{aligned}
$$

For this optimization problem, the weight matrices in the objective function are

$$
\begin{aligned}
\mathbf{W} & =\left[\begin{array}{llll}
1 & 0 & 0 & 0 \\
0 & \lambda & 0 & 0 \\
0 & 0 & 0 & 0 \\
0 & 0 & 0 & \nu
\end{array}\right], \\
\mathbf{Q} & =[0] .
\end{aligned}
$$

With the model and the objective function now expressed in the required forms, the approach is to solve for optimal discretionary rules using dynamic programming and for optimal precommitment rules through a Lagrangian. Using the preference parameters $\lambda=0.5, \nu=0$ and the parameter values from Table 1 , the laws of motion for inflation and output, and the discretionary policy rule are

$$
\begin{aligned}
& \pi_{t}=0.555 \pi_{t-1}+1.110 \varepsilon_{t}^{\pi}, \\
& y_{t}=-0.495 \pi_{t-1}-0.991 \varepsilon_{t}^{\pi},
\end{aligned}
$$




$$
i_{t}=5.000 y_{t-1}+3.888 \pi_{t-1}+10.000 \varepsilon_{t}^{y}+7.776 \varepsilon_{t}^{\pi},
$$

for $t \geq 1$, together with the initial conditions $\pi_{0}, y_{0}$ given.

For precommitment the Euler equations for optimality are (for all $t \geq 1$ )

$$
\begin{aligned}
0 & =2 \pi_{t}+\zeta_{1 t}-\delta^{-1} \varphi_{\pi} \zeta_{1 t-1}-\delta\left(1-\varphi_{\pi}\right) \mathrm{E}_{t} \zeta_{1 t+1}-\beta \delta^{-1} \zeta_{2 t-1}, \\
0 & =2 \lambda y_{t}-\alpha \zeta_{1 t}+\zeta_{2 t}-\varphi_{y} \delta^{-1} \zeta_{2 t-1}-\left(1-\varphi_{\pi}\right) \delta \mathrm{E}_{t} \zeta_{2 t+1}, \\
0 & =2 \nu\left[i_{t}-i_{t-1}\right]-2 \nu \mathrm{E}_{t}\left[i_{t+1}-i_{t}\right]-\beta \zeta_{2 t}, \\
0 & =\pi_{t}-\varphi_{\pi} \mathrm{E}_{t} \pi_{t+1}-\left(1-\varphi_{\pi}\right) \pi_{t-1}-\alpha y_{t}-\varepsilon_{t}^{\pi}, \\
0 & =y_{t}-\varphi_{y} \mathrm{E}_{t} y_{t+1}-\left(1-\varphi_{y}\right) y_{t-1}+\beta\left[i_{t}-\mathrm{E}_{t} \pi_{t+1}\right]-\varepsilon_{t}^{y},
\end{aligned}
$$

where $\zeta_{1 t}$ and $\zeta_{2 t}$ are the Lagrange multipliers corresponding to equations (A3) and (A4), respectively. Using the same parameter values, the system evolves according to ${ }^{24}$

$$
\begin{aligned}
\zeta_{1 t} & =0.509 \zeta_{1 t-1}-1.012 \pi_{t-1}-2.025 \varepsilon_{t}^{\pi}, \\
\pi_{t} & =0.083 \zeta_{1 t-1}+0.504 \pi_{t-1}+1.009 \varepsilon_{t}^{\pi}, \\
y_{t} & =0.204 \zeta_{1 t-1}-0.405 \pi_{t-1}-0.810 \varepsilon_{t}^{\pi}, \\
i_{t} & =-1.602 \zeta_{1 t-1}+5.000 y_{t-1}+2.168 \pi_{t-1}+10.000 \varepsilon_{t}^{y}+4.335 \varepsilon_{t}^{\pi},
\end{aligned}
$$

from the initial conditions $\pi_{0}, y_{0}$ given, and $\zeta_{10}=0$. The restriction that $\zeta_{10}=0$ reflects the fact that in the initial period the policymaker does not honor commitments made prior to the optimization date.

\footnotetext{
${ }^{24}$ With $\nu=0$ the constraint from the IS curve never binds, so $\zeta_{2 t}=0$ for all $t$ (see equation (A11)).
} 


\section{References}

Ball, Laurence, "Credible disinflation with staggered price-setting," American Economic Review 84 (1), 282-289, March 1994.

Barro, Robert J. and David B. Gordon, "A positive theory of monetary policy in a natural rate model," Journal of Political Economy 91 (4), 589-610, August 1983.

Batini, Nicoletta, Richard Harrison, and Stephen P. Millard, "Monetary policy rules for an open economy," Working Paper No. 149, Bank of England, December 2001.

Blake, Andrew P., "A 'timeless perspective' on optimality in forward-looking rational expectations models," Discussion Paper No. 188, National Institute of Economic and Social Research, October 2001.

Blinder, Alan S., Central Banking in Theory and Practice, The MIT Press, Cambridge, Mass., 1998.

Bryant, Ralph C., Peter Hooper, and Catherine L. Mann, Evaluating Policy Regimes: New Research in Empirical Macroeconomics, Brookings Institution, Washington, D.C., 1993.

Buiter, Willem H. and Ian Jewitt, "Staggered wage setting with real wage relativities: Variations on a theme of Taylor," Manchester School of Economic and Social Studies 49 (3), 211-228, September 1981.

Calvo, Guillermo A., "Staggered prices in a utility-maximizing framework," Journal of Monetary Economics 12 (3), 383-398, September 1983.

Chadha, Bankim, Paul R. Masson, and Guy Meredith, "Models of inflation and the costs of disinflation," International Monetary Fund Staff Papers 39 (2), 395-431, June 1992 .

Christiano, Lawrence J., Martin Eichenbaum, and Charles L. Evans, "Nominal rigidities and the dynamic effects of a shock to monetary policy," Working Paper No. 8403, National Bureau of Economic Research, July 2001.

Clarida, Richard, Jordi Galí, and Mark Gertler, "The science of monetary policy: A new Keynesian perspective," Journal of Economic Literature 37 (4), 1661-1707, December 1999.

Cukierman, Alex, "Why does the Fed smooth interest rates?" in Belongia, Michael T. (ed.), Monetary policy on the 75th anniversary of the Federal Reserve System, Kluwer Academic Publishers, Boston, 1991.

Currie, David and Paul Levine, Rules, Reputation and Macroeconomic Policy Coordination, Cambridge University Press, 1993. 
Dennis, Richard, "Solving for optimal simple rules in rational expectations models," Working Paper No. 2000-14 (revised version), Federal Reserve Bank of San Francisco, March 2000.

_ , "Optimal policy in rational-expectations models: New solution algorithms," Working Paper No. 2001-09, Federal Reserve Bank of San Francisco, July 2001a.

-, "The policy preferences of the U.S. Federal Reserve," Working Paper No. 2001-08, Federal Reserve Bank of San Francisco, July 2001b.

- "Pre-commitment, the timeless perspective, and policymaking from behind a veil of uncertainty," Working Paper No. 2001-19, Federal Reserve Bank of San Francisco, October 2001c.

Ehrmann, Michael and Frank Smets, "Uncertain potential output: Implications for monetary policy," Working Paper No. 59, European Central Bank, April 2001. Forthcoming, Journal of Economic Dynamics and Control.

Erceg, Christopher J., Dale W. Henderson, and Andrew T. Levin, "Optimal monetary policy with staggered wage and price contracts," Journal of Monetary Economics 46 (2), 281-313, October 2000.

Estrella, Arturo and Jeffrey C. Fuhrer, "Dynamic inconsistencies: Counterfactual implications of a class of rational expectations models," Working Paper No. 98-5, Federal Reserve Bank of Boston, July 1998. Forthcoming, American Economic Review.

Fuhrer, Jeffrey C., "Inflation/output variance trade-offs and optimal monetary policy," Journal of Money, Credit, and Banking 29 (2), 214-234, May 1997a.

— monetary policy analysis," Carnegie-Rochester Conference Series on Public Policy 47, 197-230, December 1997b.

- "The (un)importance of forward-looking behavior in price specifications," Journal of Money, Credit, and Banking 29 (3), 338-350, August 1997c.

_ _ "Habit formation in consumption and its implications for monetary-policy models," American Economic Review 90 (3), 367-390, June 2000.

Fuhrer, Jeffrey C. and George Moore, "Inflation persistence," Quarterly Journal of Economics 110 (1), 127-159, February 1995a.

_- "Monetary policy trade-offs and the correlation between nominal interest rates and real output," American Economic Review 85 (1), 219-239, March 1995b.

Galí, Jordi and Mark Gertler, "Inflation dynamics: A structural econometric analysis," Journal of Monetary Economics 44 (2), 195-222, October 1999. 
Gerlach, Stefan and Frank Smets, "Output gaps and monetary policy in the EMU area," European Economic Review 43 (4-6), 801-812, April 1999.

Giannoni, Marc P. and Michael Woodford, "Optimal interest-rate rules," manuscript, Princeton University, December 2001.

Goodfriend, Marvin, "Interest rates and the conduct of monetary policy," CarnegieRochester Conference Series on Public Policy 34, 7-30, Spring 1991.

Huh, Chan G. and Kevin J. Lansing, "Expectations, credibility, and disinflation in a small macroeconomic model," Journal of Economics and Business 52 (1-2), 51-86, January 2000.

Ireland, Peter N., "Does the time-consistency problem explain the behavior of inflation in the United States?" Journal of Monetary Economics 44 (2), 279-291, October 1999.

Jensen, Henrik, "Targeting nominal income growth or inflation?" manuscript, University of Copenhagen, August 2001. Forthcoming, American Economic Review.

King, Robert G. and Alexander L. Wolman, "What should the monetary authority do when prices are sticky?" in Taylor, John B. (ed.), Monetary Policy Rules, University of Chicago Press, 1999.

Kydland, Finn E. and Edward C. Prescott, "Rules rather than discretion: The inconsistency of optimal plans," Journal of Political Economy 85 (3), 473-491, June 1977.

- "Dynamic optimal taxation: Rational expectations and optimal control," Journal of Economic Dynamics and Control 2 (1), 79-91, February 1980.

Levin, Andrew, Volker Wieland, and John C. Williams, "Robustness of simple monetary policy rules under model uncertainty," in Taylor, John B. (ed.), Monetary Policy Rules, University of Chicago Press, 1999.

Lindé, Jesper, "Estimating New-Keynesian Phillips curves: A full information maximum likelihood approach," Working Paper No. 129, Sveriges Riksbank, April 2002. (Revised version).

Lowe, Philip and Luci Ellis, "The smoothing of official rates," in Lowe, Philip (ed.), Monetary Policy and Inflation Targeting, Reserve Bank of Australia, 1997.

McCallum, Bennett T., "Crucial issues concerning central bank independence," Journal of Monetary Economics 39 (1), 99-112, June 1997.

McCallum, Bennett T. and Edward Nelson, "An optimizing IS-LM specification for monetary policy and business cycle analysis," Journal of Money, Credit, and Banking 31 (3), 296-316, August 1999. 
- "Timeless perspective vs. discretionary monetary policy in forward-looking models," Working Paper No. 7915, National Bureau of Economic Research, September 2000.

Nessén, Marianne and David Vestin, "Average inflation targeting," Working Paper No. 119, Sveriges Riksbank, December 2000.

Orphanides, Athanasios and Volker Wieland, "Price stability and monetary policy effectiveness when nominal interest rates are bounded at zero," Finance and Economics Discussion Paper No. 1998-35, Board of Governors of the Federal Reserve System, June 1998.

_ , "Inflation zone targeting," European Economic Review 44 (7), 1351-1388, June 2000 .

Roberts, John M., "New Keynesian economics and the Phillips curve," Journal of Money, Credit, and Banking 27 (4), 975-984, November 1995. 1997.

Rotemberg, Julio J., "Monopolistic price adjustment and aggregate output," Review of Economic Studies 49 (4), 517-531, October 1982.

Rotemberg, Julio J. and Michael Woodford, "An optimization-based econometric framework for the evaluation of monetary policy," in Bernanke, Ben S. and Julio J. Rotemberg (eds.), NBER Macroeconomics Annual, The MIT Press, Cambridge, Mass., 1997.

Rudebusch, Glenn D., "Assessing nominal income rules for monetary policy with model and data uncertainty," Economic Journal 112, 1-31, April 2002.

Rudebusch, Glenn D. and Lars E. O. Svensson, "Policy rules for inflation targeting," in Taylor, John B. (ed.), Monetary Policy Rules, University of Chicago Press, 1999.

Sargent, Thomas J., The Conquest of American Inflation, Princeton University Press, 1999.

Smets, Frank, "What horizon for price stability?" Working Paper No. 24, European Central Bank, July 2000.

Smets, Frank and Raf Wouters, "An estimated stochastic dynamic general equilibrium model of the euro area," manuscript, European Central Bank, May 2002.

Söderström, Ulf, "Targeting inflation with a prominent role for money," Working Paper No. 123, Sveriges Riksbank, June 2001. 
Söderström, Ulf, Paul Söderlind, and Anders Vredin, "Can a calibrated NewKeynesian model of monetary policy fit the facts?" Working Paper No. 140, Sveriges Riksbank, September 2002.

Steinsson, Jón, "Optimal monetary policy in an economy with inflation persistence," Working Paper No. 11, Central Bank of Iceland, December 2000.

Svensson, Lars E. O., "Inflation forecast targeting: Implementing and monitoring inflation targets," European Economic Review 41 (6), 1111-1146, June 1997a.

— - "Optimal inflation targets, 'conservative' central banks, and linear inflation contracts," American Economic Review 87 (1), 98-114, March 1997b.

_ - "Inflation targeting as a monetary policy rule," Journal of Monetary Economics 43 (3), 607-654, June 1999.

Svensson, Lars E. O. and Michael Woodford, "Implementing optimal policy through inflation-forecast targeting," manuscript, Institute for International Economic Studies, Stockholm University, November 1999.

Taylor, John B., "Estimation and control of a macroeconomic model with rational expectations," Econometrica 47 (5), 1267-1286, September 1979.

- "Aggregate demand dynamics and staggered contracts," Journal of Political Economy 88 (1), 1-23, February 1980a.

_- "Output and price stability: An international comparison," Journal of Economic Dynamics and Control 2 (1), 109-132, February 1980b.

— Monetary Policy Rules, University of Chicago Press, 1999.

Vestin, David, "Price-level targeting versus inflation targeting in a forward-looking model," Working Paper No. 106, Sveriges Riksbank, May 2000.

, "The size of the commitment problem," manuscript, Institute for International Economic Studies, Stockholm University, May 2001.

Walsh, Carl E., Monetary Theory and Policy, The MIT Press, Cambridge, Mass., 1998.

— mimeo, University of California, Santa Cruz, April 2001. Forthcoming, American Economic Review.

Woodford, Michael, "Commentary: How should monetary policy be conducted in an era of price stability?" in New Challenges for Monetary Policy, Federal Reserve Bank of Kansas City, 1999a.

_ , "Optimal monetary policy inertia," Working Paper No. 7261, National Bureau of Economic Research, July 1999b. 
- "Inflation stabilization and welfare," Working Paper No. 8071, National Bureau of Economic Research, January 2001. 